\title{
O Serviço de Documentação Textual e Iconografia do Museu Paulista'
}

\author{
Miyoko Makino \\ Shirley Ribeiro da Silva \\ Solange Ferraz de Lima \\ Vânia Carneiro de Carvalho \\ Museu Paulista da USP
}

Breve histórico

Desde a reorganização administrativa realizada em abril de 1997, o Serviço de Documentação Textual e lconografia (SVDHICO) integra - com os Serviço de Objetos, Serviço de Laboratório de Conservação e Restauração, Serviço de Museografia e Comunicação Visual e Serviço de Atividades Educativas - a Divisão Técnico-Científica de Acervo e Curadoria (DAC). A DAC, somada à Divisão de Difusão Cultural (DDC) e à Biblioteca, concentram as atividades-fim do Museu Paulista. Nelas estão abrigados os acervos, as funções científicas da área de nossa especialidade - cultura material e história - e as atividades culturais e pedagógicas.

Atualmente o SVDHICO reúne tipologias textuais e iconográficas organizadas em mais de duas centenas de coleções e fundos de arquivo. Neste Serviço estão também disponíveis a produção documental gerada pelo próprio Museu entre 1893-1963, que tecnicamente denominada Fundo Museu Paulista, constitui-se por sua vez em um dos dois ramos do Arquivo Permanente do Museu Paulista 2 . Originariamente o SVDHICO era parte da "Seção de História", esta com existência administrativa informal até 1922. Nesta data, não por acaso, a Lei n. 1.911 formalizou a seção com o nome de Seção de História Nacional e Etnografia. Inexpressiva até o ingresso de Affonso d'Escragnolle Taunay como diretor do Museu (1917-1945), por ocasião das comemorações do Centenário da Independência, em 1922, as pesquisas e a ampliação dos acervos históricos tomaram um novo impulso. Essa inflexão marcaria a transição longa, mas inelutável, de um museu de história natural para o museu histórico que hoje se conhece.

Em 1925, eram atribuições da Seção de História Nacional e Etnografia "reunir documentos sobre o passado nacional, principalmente quanto
1. O Serviço de DocumentaçãoTextual e Iconografia é integrado por Vânia Carneiro de Carvalho (supervisora), Solange Ferraz de Lima (pesquisadora), Miyoko Makino (responsável pelo Setor de Pinacoteca) e Shirley Ribeiro da Silva (técnica de museu). Conta regularmente com profissionais contratados temporariamente para projetos patrocinados pelo Fundo de Pesquisa do Museu Paulista, e com estudantes financiados pelo Coseas através de bolsastrabalho e pelo Fundo da Pró-Reitoria de Cultura e Extensão.

2. O outro ramo é o Fundo do Museu Republicano Convenção de Itu, que é parte da Museu Paulista. 
ao de São Paulo, esparsos pelos Arquivos e Bibliotecas públicos e privados" e "promover reconstituições referentes aos principais fatos da História do Brasil e de São Paulo" (TESSIT́ORE; CARVALHO, 1992). Tais responsabilidades explicam a proliferação de reproduções de documentos textuais e iconográficos oriundos de acervos particulares, institucionais e estrangeiros, que se encontram atualmente no SVDHICO. Trata-se de duplicatas produzidas principalmente na gestão de Taunay, ávido por "reconstituir" o repertório textual e iconográfico disponível sobre a cidade de São Paulo e sobre os personagens emblemáticos da formação da nação brasileira.

Apesar do prestígio e investimento governamental que tal segmento do Museu passou a receber desde o ingresso de Taunay le durante o curto período do diretor Armando Prado, 1916 - 1917), foi somente em 1936 que, pela primeira vez, um assistente foi nomeado para esta Seção desde a criação do Museu.

A Seção de História Nacional e Etnografia tornou-se a única seção formalmente constituída no Museu Paulista entre os anos de 1939 e 1946, após a saída das Seções de Botânica (1927) e de Zoologia (1939). O Decreto-Lei n. 16.565, de 27 de dezembro de 1946, promoveu o seu primeiro desmembramento, dividindo-a nas Seções de Numismática, Etnologia e História Nacional. Estrutura que permaneceu até 1963, quando o Museu Paulista foi incorporado à Universidade de São Paulo.

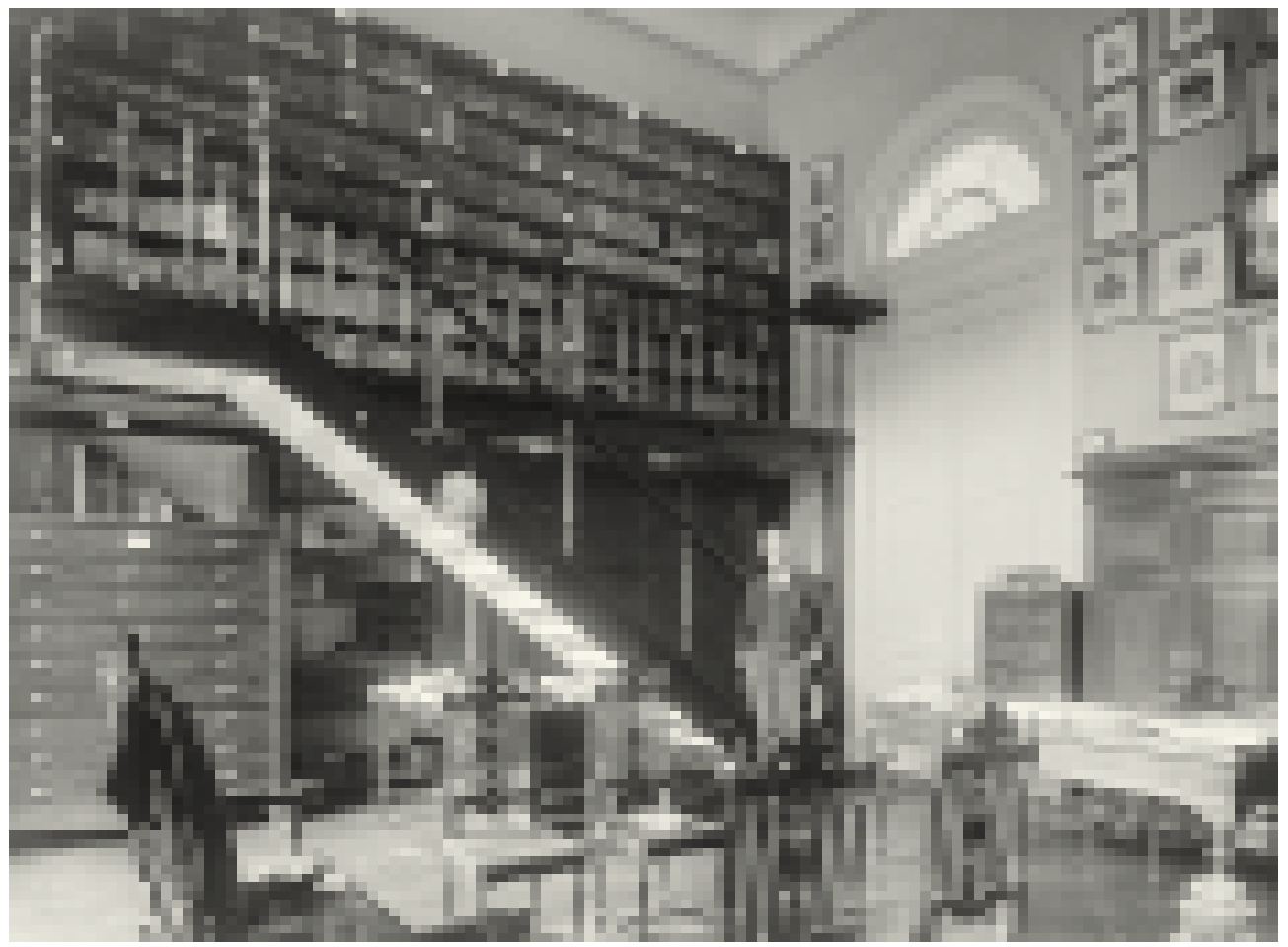

FIGURA 1 - Afonso de Escragnolle Taunay no gabinete da diretoria do Museu Paulista (1917/ 1945), fotografia p\&b, gelatina, $14 \times 18 \mathrm{~cm}$. Coleção Taunay. Acervo Museu Paulista da USP. Reprodução de Hélio Nobre. 
A incorporação à Universidade aprofundou o perfil científico da instituição, aumentando seu quadro técnico-científico. Pelo Regimento do Museu Paulista de 19843, o "Centro de Documentação"4 fazia parte da Equipe Técnicocientífica de História, da Área Científica, até o Regimento de 1997.

Em diagnóstico realizado em 1991 , tínhamos a seguinte configuração do então Setor de Documentação do Museu Paulista - 28 conjuntos documentais, entre fundos e coleções, tanto de origem pública quanto privada, perfazendo a ordem de grandeza de 300 metros lineares (TESSITORE; CARVALHO, 1991). Parte destes conjuntos era constituída por exemplares de jornais do século XIX, o que resultou na formação de uma hemeroteca reunindo cerca de 300 títulos. As datas-limite estão entre os séculos XVIII e XX, com ênfase no século XIX e nas duas primeiras décadas do século XX. As principais coleções são de personalidades igadas à política e à cultura, tanto no âmbito regional paulista como no nacional. Nos últimos dez anos este universo textual foi ampliado para 123 conjuntos documentais, entre os quais destacam-se os seguintes fundos e coleções (dos quais muitos integram, além de documentação textual, documentos iconográficos e tridimensionais): Affonso de Escragnolle Taunay (com último lote recém-adquirido da família) (FIGURA 1), Alberto Santos Dumont, Antônio Carlos Gomes, barão de Atibaia, barão de Ramalho, barão do Rio Branco, Bento Augusto de Almeida Bicudo, Eduardo Paulo da Silva Prado, Eugênio de Andrada Egas, família Morais Barros, Fernando Pacheco Chaves, Harold Alexandre Hummel, João Baptista de Campos Aguirra, José Bonifácio de Andrada e Silva, marquês de Monte Alegre, Mário Neme, Olga de Souza Queiroz, Pedro Manoel de Toledo, Marquês de Valença, Synésio Rangel Pestana, Tommaso Gaudenzio Bezzi, família Jafet, Militão e Luís Gonzaga de Azevedo, entre muitos outros (TESSITORE; CARVALHO, 1998). As coleções e fundos mais antigos e de renome foram catalogados durante as décadas de 1970 e 1980. O catálogo e o Guia das Coleções e dos Fundos Textuais constituem os instrumentos de pesquisa disponíveis para a consulta à documentação (FIGURA 2).

Ao longo de sua trajetória de acumulação de documentos por doação ou compra, o então Setor de Documentação integrou ao seu acervo aproximadamente 19 mil documentos iconográficos. A grande maioria desses documentos permaneceu junto com a documentação textual (principalmente os retratos em pequeno formato, como os cartões de visita, gabinetes e postais), sem um tratamento especializado. As pinturas foram exceção nesse quadro de baixa valorização da iconografia como objeto de estudo. Contaram, desde cedo, com uma catalogação unitária diferentemente das fotografias e dos documentos impressos (cartazes, figurinhas, postais entre outros), pois estavam integradas ao inventário geral dos objetos tridimensionais.

Década de 1990: a nova política de aquisição e programa de reorganização física e documental dos acervos alteram o perfil do Serviço

Em 1989, o Museu Paulista da USP sofreu uma nova reformulação. Neste ano, as áreas antropológicas foram transferidas para o novo Museu de Arqueologia e Etnologia da USP, permanecendo no Museu Paulista somente a equipe técnico-científica de História. As condições estruturais e conceituais para
3. A Resolução 2822, de 30-11-84, baixou o Regimento Interno do Museu Paulista em atendimento ao artigo 30 da Resolução 2342, de 08-01-82, que baixou o Regimento dos Museus da USP

4. Assim chamada informalmente. 


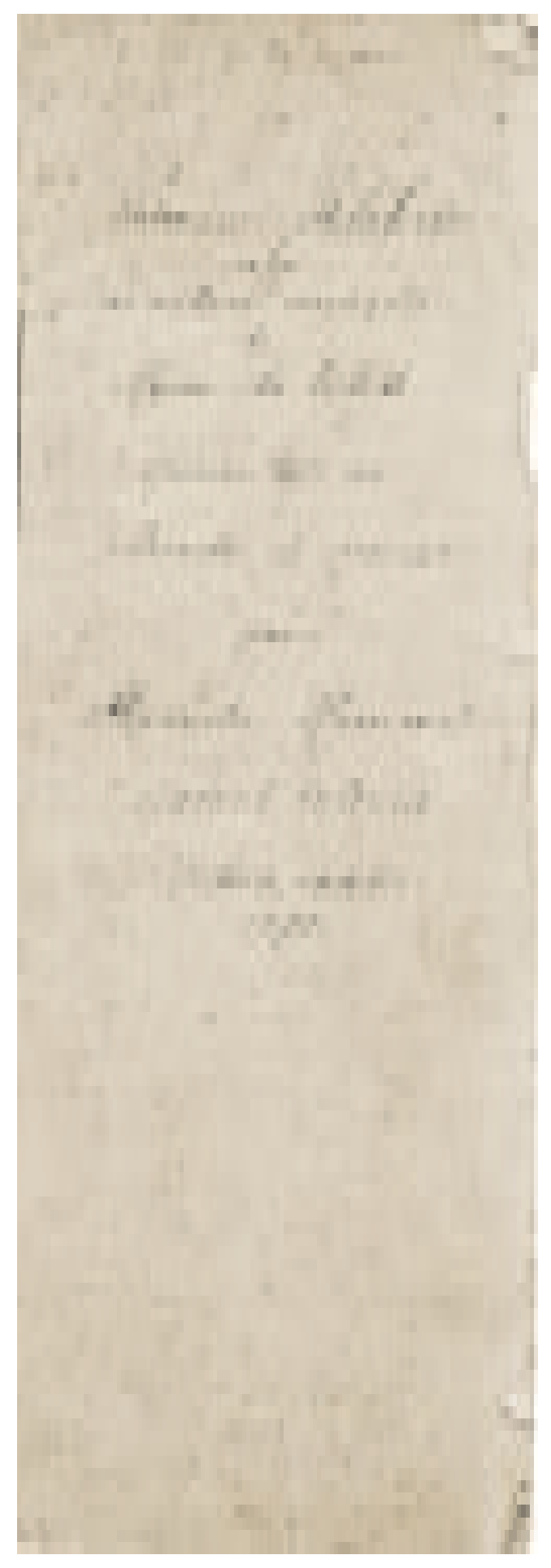

FIGURA 2 - Primeiro Relatório sobre as actuaes condições do Museu do Estado apresentado ao Director do mesmo por Alexandre Hummel, ajudante interino. S.Paulo, outubro, 1891, 31 p. Coleção Hummel. Acervo Museu Paulista da USP. Reprodução de Hélio Nobre. 
que o Museu se tornasse um museu histórico universitário encontram-se sistematizadas no Plano Diretor de 1990, e foram mantidas pela gestões seguintes (MENESES, 1990; MUSEU PAULISTA, 1997, 2000). Levando em conta o perfil dos acervos existentes e os pressupostos de seu novo campo de atuação - história e cultura material -, foram definidas as três linhas de pesquisa - Cotidiano e Sociedade; História do Imaginário e Universo do Trabalho - que orientam desde a política de formação e ampliação dos acervos até os projetos acadêmicos e seus desdobramentos em áreas da difusão cultural e educacional, através de exposições, cursos e demais produtos dirigidos ao público em geral.

A reformulação promovida em 1989 proporcionou ao museu um campo de atuação específico e delimitado. No entanto, uma das conseqüências desta especialização foi a redução do quadro docente e técnico, devido à transferência para o MAE das equipes das áreas antropológicas. Mesmo depois dos concursos, que promoveram a integração de dois museólogos e três historiógrafos ao quadro funcional, a equipe manteve-se ainda muito reduzida diante das responsabilidades decorrentes do novo perfil. Além disso, a instituição teve de lutar (e ainda luta) contra as agruras de uma política geral universitária de redução de quadros (FIGURAS 3,4).

Apesar da defasagem entre o que estava projetado para este "novo museu" e suas efetivas realizações, é inquestionável que, nos últimos 13 anos, o Museu respondeu à especialização desejada através de ações que resultaram na ampliação e no tratamento físico e documental dos acervos, na produção de conhecimento científico e sua difusão. Tal prática curatorial fundamenta-se numa relação solidária entre todas as atividades que envolvem o acervo e a pesquisa. Estes dois eixos direcionam a produção de coleções e de um sistema documental dos quais dependem, por sua vez, a qualidade da pesquisa e a manutenção e crescimento do acervo.

As equipes entenderam que o início deste processo curatorial dependia de um esforço em tratar cientificamente milhares de unidades de um acervo em grande parte já centenário na instituição. $\bigcirc$ que significou a aplicação de novas formas de organização e descrição necessariamente associadas a projetos de infra-estrutura e tecnólogia, especialmente na área de informática, e que foram apoiados por sucessivos projetos-FAPESP e pela própria Universidade.

No SVDHICO, dentro desse novo programa de reestruturação, impôsse como prioritária a reorganização física e documental das coleções textuais e dos documentos arquivísticos produzidos pelo Museu, bem como o desenvolvimento de metodologia para a catalogação dos suportes iconográficos, que permitisse a sua qualificação como documento para a pesquisa. Assim, entre 1991 e 1994, com financiamento da FAPESP, o atual SVDHICO produziu o Guia das Coleções Textuais e o Inventário do Arquivo Permanente do Museu Paulista (TESSITÓRE; CARVALHO, 1994, 1998).

Guia das Coleções e dos Fundos Textuais do SVDHICO é um instrumento de pesquisa abrangente, que tem como objetivo fornecer ao consulente uma ficha sucinta de toda a documentação textual. A elaboração do guia teve início com a identificação dos conjuntos documentais, redefinição de seu status (Fundo, Coleção, Documento Avulso), levantamento de dados sobre a situação de entrada dos documentos e histórico do titular. Todos os dados relativos a cada núcleo documental foram centralizados na Ficha de Registro de Entrada (ficha de controle da documentação). Nesta ficha os documentos são registrados por lote (de entrada) e recebem um número de registro acoplado à sigla $A R Q$. As categorias 
Número de Docentes e Pesquisadores do Museu Paulista da USP

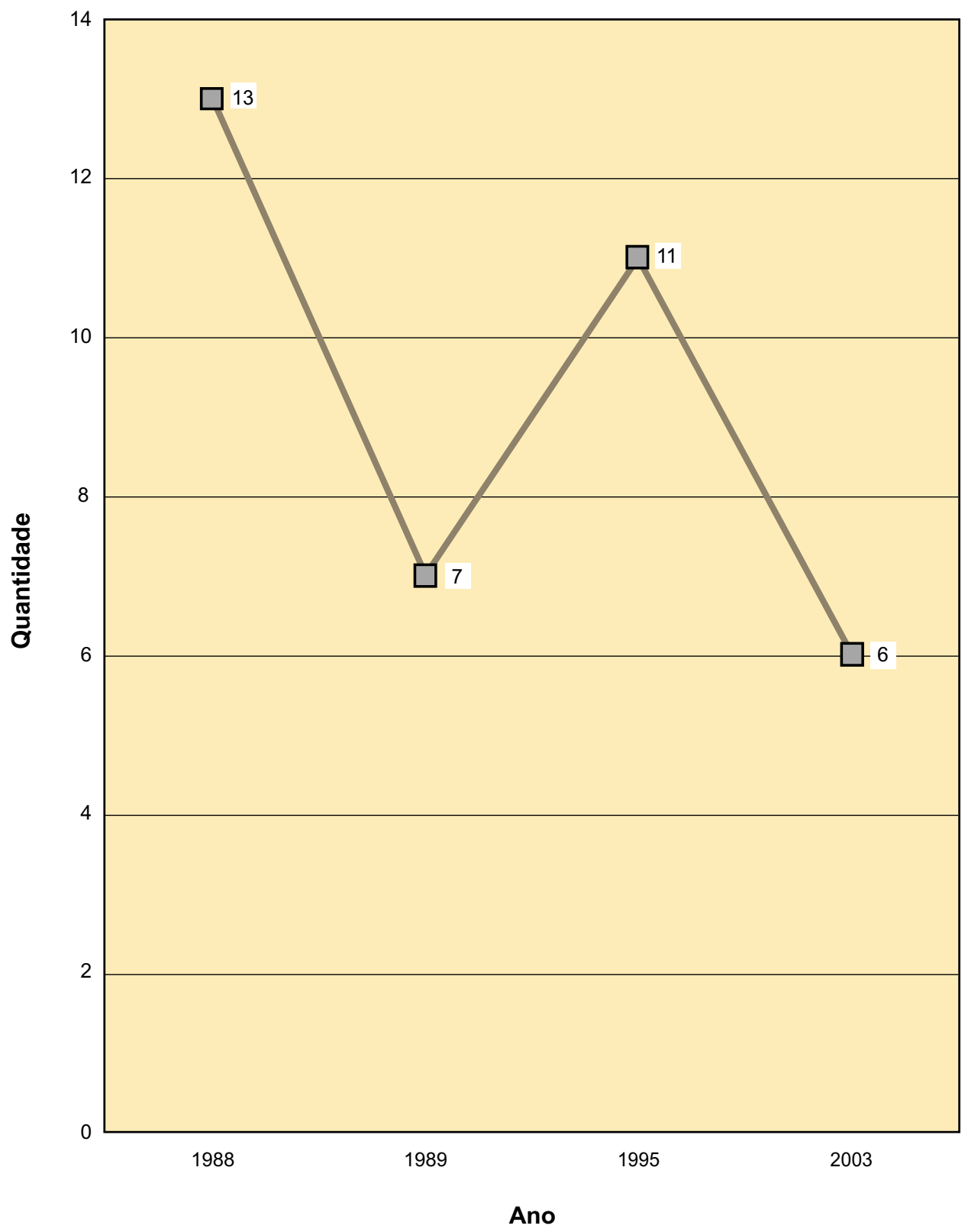

FIGURA 3 - Docentes e Pesquisadores 
Número de Funcionários do Museu Paulista da USP (Nível Superior / Técnico / Básico)

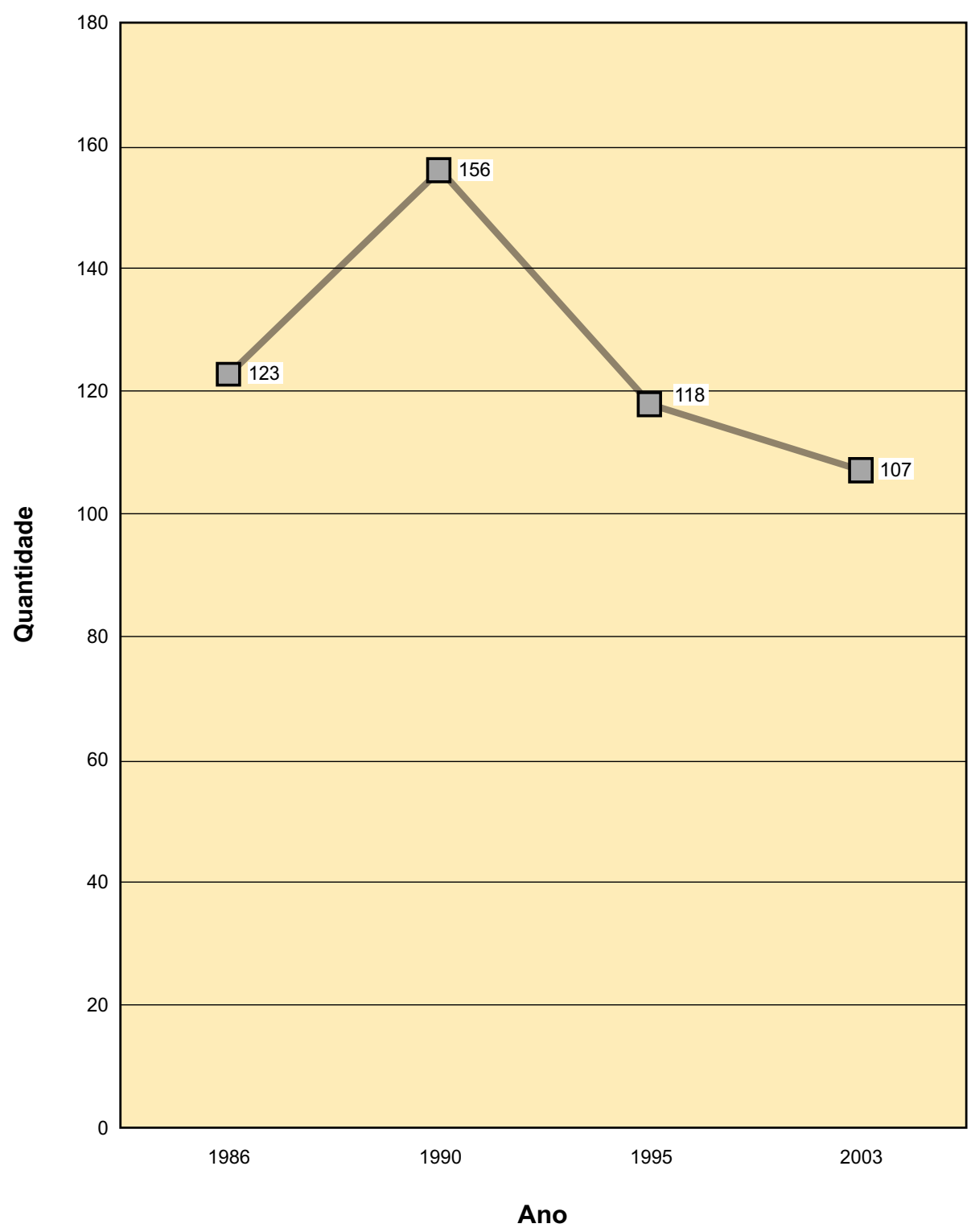


de informações nela presentes estão vinculadas às Fichas de lconografia (IC) e de Objetos (RG) (BARBUY; CARVALHO; LIMA, 2002, p. 13-19).

$\bigcirc$ projeto de organização física do Arquivo Permanente do Museu Paulista reuniu no SVDHICO documentos produzidos pela instituição entre 1893 e 1963, que se encontravam dispersos em salas de pesquisadores, "arquivosmortos" da equipe de pesquisa e seções administrativas. Reunidos e organizados em grupos, subgrupos e séries documentais, estes documentos estão referenciados no intrumento de pesquisa Inventário do Arquivo Permanente do Museu Paulista, que tem fomentado diversas inverstigações sobre a instituição museológica, o Museu, os intelectuais e artistas que por ele passaram, com se verá mais adiante.

Para a documentação iconográfica, também contou-se com o apoio de uma agência de pesquisa - o CNPq - que financiou o projeto Banco de Dados lconográficos (CNPq, 1992-95). Seu objetivo central era a formatação de um banco de dados, que referenciasse coleções dispersas em inúmeras instituições, segundo recortes cronológicos e tipológicos, e que propiciasse o desenvolvimento de problemáticas ligadas às linhas de pesquisa da instituição: Iconografia Publicitária (espaço doméstico); Iconografia Fotográfica Urbana (álbuns de família e cartões postais) e lconografia Impressa (caricatura). $\bigcirc$ projeto financiou 12 bolsistas de iniciação científica e aperfeiçoamento engajados no levantamento, catalogação e descrição dessas coleções. Experiência que pemitiu o desenvolvimento-piloto do módulo iconográfico do catálogo institucional.

Em paralelo, no interior da comissão de informática (que reunia todos os curadores que trabalhavam diretamente com o acervo do Museu), deu-se início ao desenho da ficha catalográfica e às pesquisas em torno de softwares capazes de atender às necessidades de documentação do acervo. Era consenso na comissão a necessidade de programa e equipamentos que permitissem a digitalização de reproduções do acervo e a consulta conjugada - ficha e imagem. Por incrível que pareça, há 13 anos essa tecnologia começava a ser desenvolvida, com experiências isoladas e pioneiras no Canadá e França (ALSFORD; GRANGER, 1987; BEARMAN, 1987; BESSER, 1987; CACALY, 1989; PATRIMOINE PHOTOGRAPHIQUE, 1987; PAYSAGE DU VIDEODISQUE, 1986). No âmbito da Universidade de São Paulo, naquele momento, dos quatro museus universitários (MAC, MAE, MZ e MP), o Museu Paulista era o único que trabalhava nesta direção, dando início efetivamente à informatização de seus acervos. Órgãos de apoio a projetos de informatização da Universidade, como é o caso do CCE (Centro de Computação Eletrônica), não estavam familiarizados com a tecnologia ou mesmo com a idéia de banco de imagens.

Para os pesquisadores responsáveis pelo módulo iconográfico, que atenderia as necessidades de parte do SVDHICO, o pressuposto para tal investimento pautava-se no reconhecimento do papel estratégico desempenhado pela iconografia nos estudos de cultura material e demais modalidades de história e antropologia cultural.

Pesquisa e coleções iconográficas

Parte da iconografia retratista, de paisagens urbanas e rurais, tipos e costumes, reunida predominantemente ao longo da gestão Taunay foi marcada 
por um cunho personalista, vinculado à representação de homens públicos e de destaque no cenário político brasileiro oitocentista e momentos significativos da história paulista. Tais representações concentraram-se em suportes considerados de envergadura para um museu, como as pinturas e gravuras. A formação da coleção de pinturas do Museu (óleos e aquarelas) está vinculada em parte a doações de famílias e, de outra parte, às encomendas públicas realizadas por Taunay a artistas tais como Oscar Pereira da Silva, José Wasth Rodrigues e Benedito Calixto de Jesus, em seu afã de constituir séries iconográficas abordando diferentes episódios da história paulista e nacional (FIGURAS 5-8).

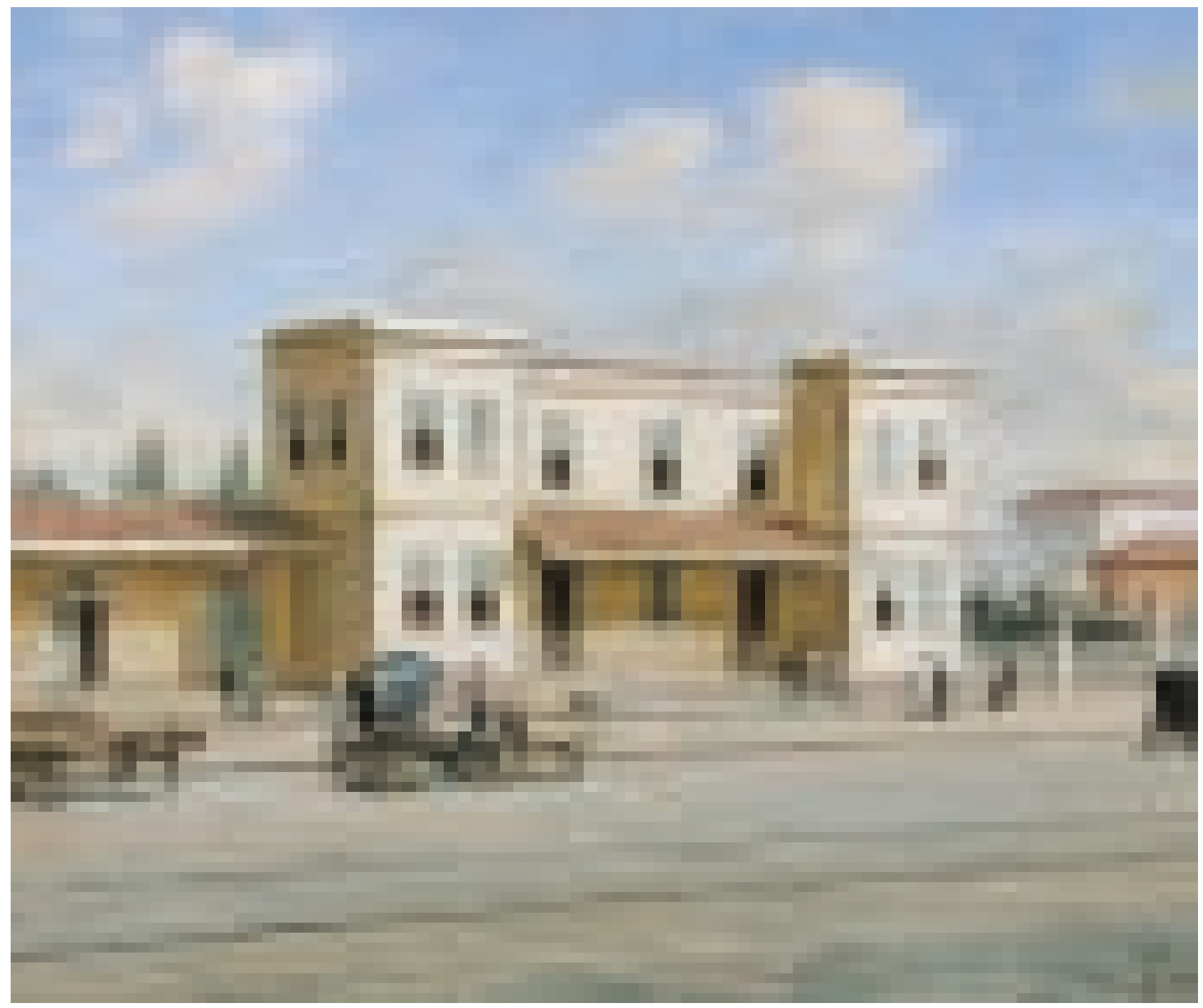

FIGURA 5 - Estação da Luz 1880, Benedito Calixto de Jesus (1 853-1927),óleo sobre tela, $60 \times 50 \mathrm{~cm}$. Acervo Museu Paulista da USP. Reprodução de José Rosael. 


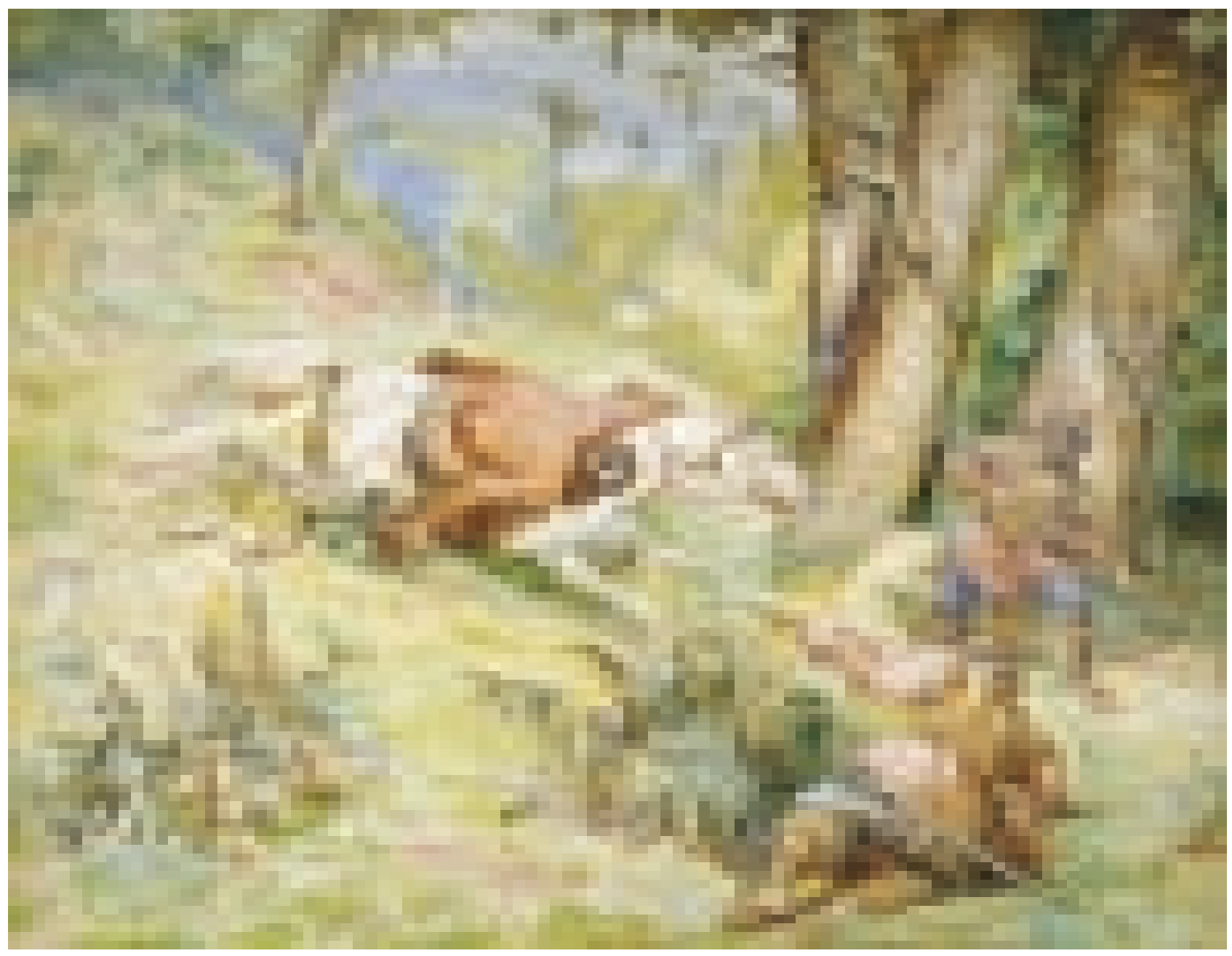

FIGURA 6 - Combate de bandeirantes de Mogi com Guaicurús, Maria José Botelho Egas, óleo sobre tela, $63 \times 50 \mathrm{~cm}$. Acervo Museu Paulista da USP. Reprodução de José Rosael. 


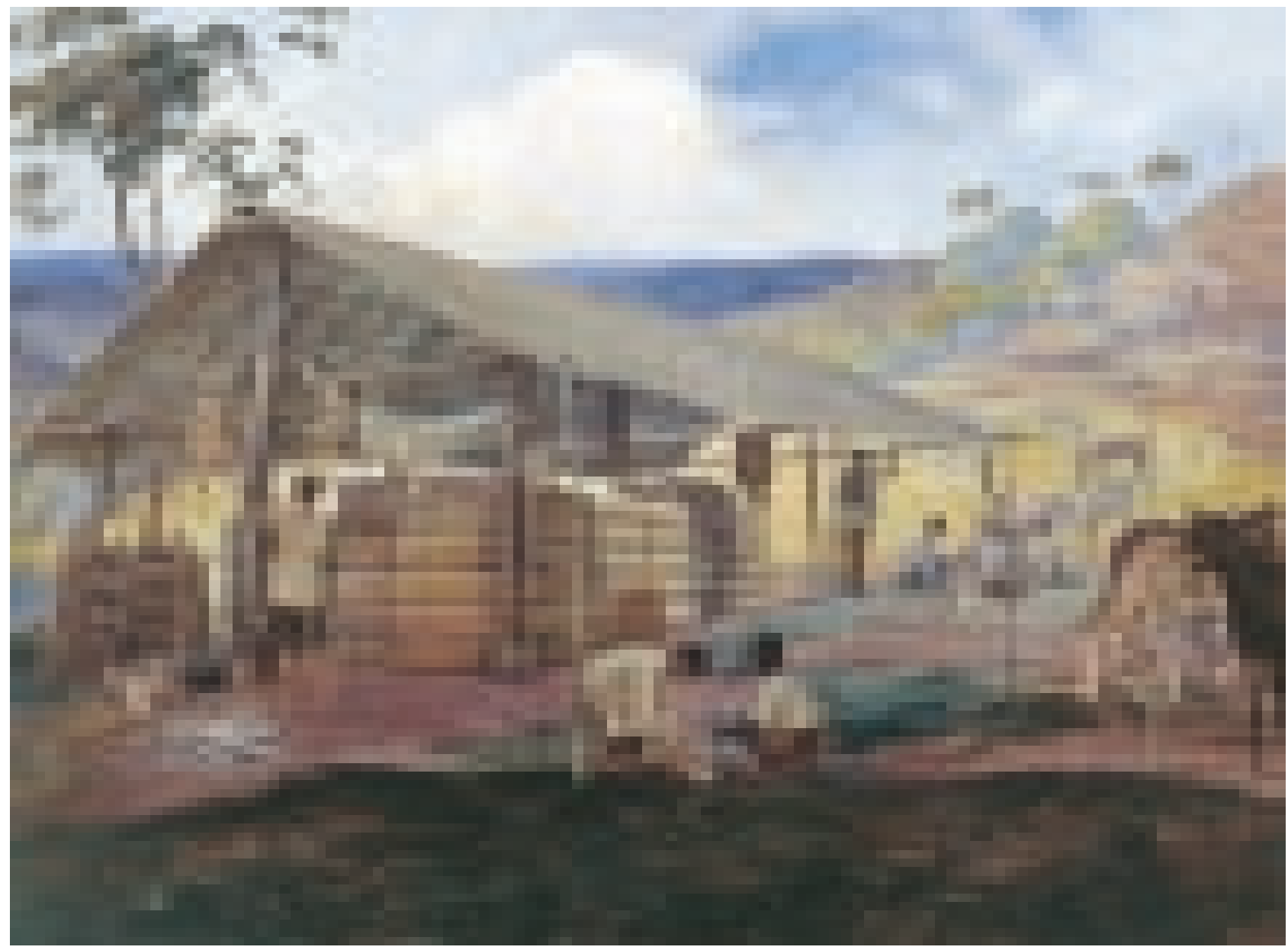

FIGURA 7 - Pouso de Tropeiros, Cubatão, 1826, Franta Richter, óleo sobre tela, $146 \times 110$ $\mathrm{cm}$. Desenho original de Hercules Florence. Acervo Museu Paulista da USP. Reprodução de José Rosael. 


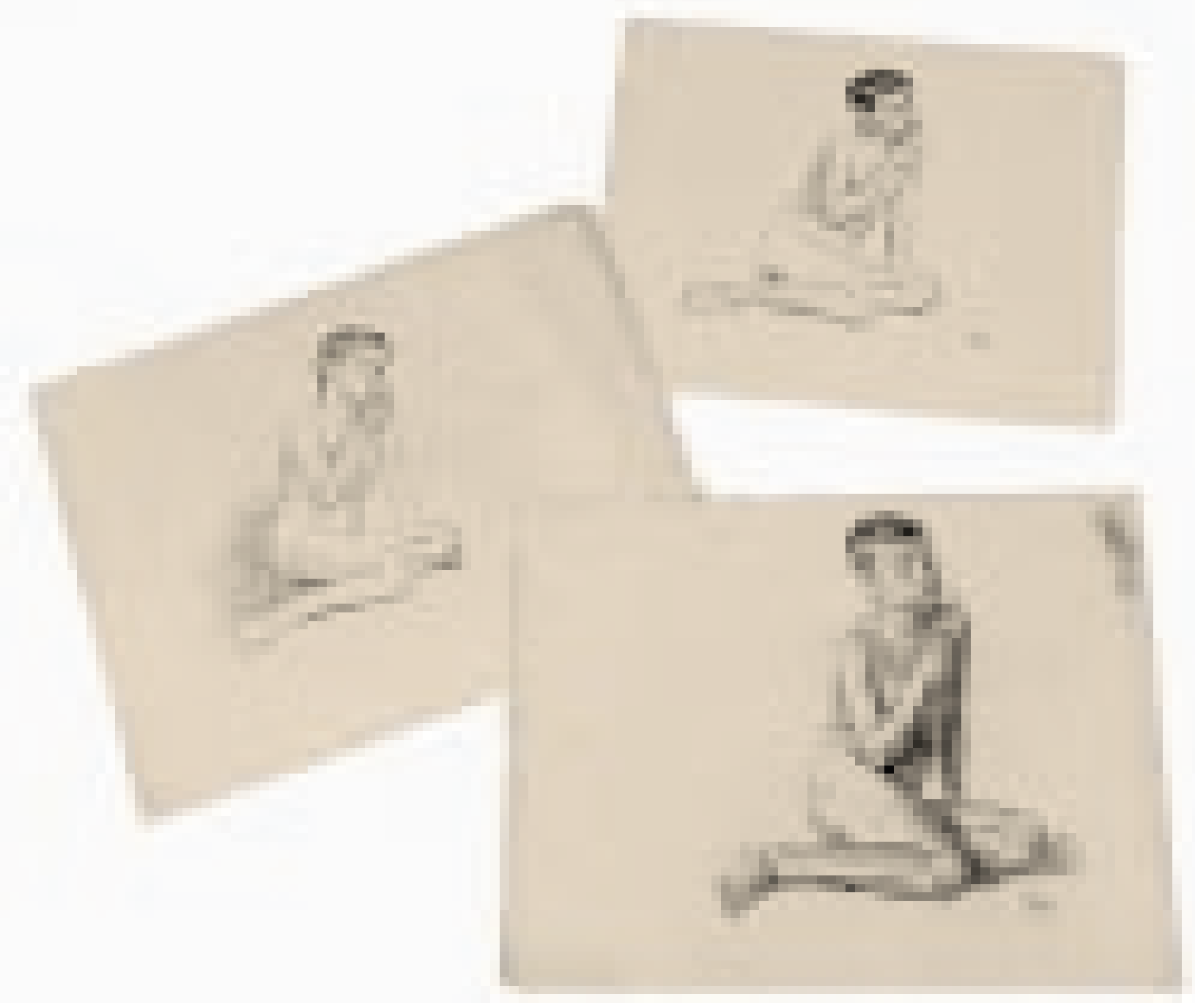
Museu Paulista da USP. Reprodução de Hélio Nobre. 
À sombra destas estavam também retratos fotográficos de famílias, bem como paisagens urbanas e rurais que, em sua grande maioria, acompanhavam os conjuntos de documentos textuais já referidos.

Ao proceder à reorganização física dos documentos, surgiu a oportunidade de contabilizar esta iconografia fotográfica, e com isto obteve-se uma noção mais clara de sua riqueza para os estudos vinculados às linhas de pesquisa História do Imaginário e Cotidiano e Sociedade. Dando continuidade a esta vocação expressa no perfil de acumulação dos documentos iconográficos no Museu, concentrou-se esforços no fomento de coleções de retratos fotográficos, álbuns de família e paisagens relacionadas à cidade de São Paulo. Ao longo de mais de uma década de uma política de aquisição e doação seletivas, hoje - Museu soma a seu acervo fundantes coleções que se destacam no cenário institucional, tornando-o referência obrigatória para pesquisadores, que incorporaram as fontes iconográficas em suas análises. A apresentação de algumas delas será útil para a compreensão do trabalho de curadoria desenvolvido neste Serviço.

A coleção doada por Orôncio Vaz de Arruda, formada por retratos de famílias paulistanas entre 1880 e 1940 (560 ampliações com predominância dos formatos cartão de visita e gabinete, mostrando cenas de casamento, batismo, aniversário, formatura, carnaval, lazer, etc., veio ao Museu incentivada pela divulgação da aquisição dos retratos da coleção Militão (FIGURA 9).

A coleção Carlos Eugênio Marcondes de Moura, adquirida com o patrocínio do Banco do Estado de São Paulo (BANESPA) e com o apoio do Ministério da Cultura, compreende um total de 2.443 fotografias, 17 álbuns e 17 negativos de vidro, a maioria proveniente da segunda metade do século XIX, produzida no Brasil e em países europeus. O maior conjunto é de retratos avulsos (1.259 unidades) nos formatos cartão de visita $(6 \times 11 \mathrm{~cm})$ e gabinete $(11 \times 16 \mathrm{~cm})$, cujo consumo foi intenso nas décadas de 1850 e 1860, respectivamente, até meados do século XX. Outras centenas de fotografias (856 unidades) estão nos álbuns. Os álbuns da coleção Carlos Eugênio merecem destaque pela exuberância de formas e materiais - fechos de metal, páginas com molduras ornamentadas, lombadas douradas, capas em couro decorado em alto e baixo relevo (uma del-as em couro de crocodilo), veludos lisos e estampados, madeira entalhada, alabastro, a maioria com incrustações em metal desenhando arranjos florais e imagens figurativas que envolvem o espaço reservado para o monograma da família - características que são a evidência do lugar de destaque social conquistado pela fotografia neste período. Interessado na genealogia das famílias de Guaratinguetá, no Vale do Paraíba Paulista, Carlos Eugênio foi aos poucos reunindo fotografias de vários ramos de sua própria família - os Marcondes de Moura, os Marcondes Guimarães, os Galvão França, entre outros. A estes núcleos juntaram-se fotografias adquiridas em antiquários e feiras de antigüidade, além de doações de amigos. Em 1983, parte dos documentos foram expostos no Museu da Imagem e do Som, em São Paulo, e analisados no livro Retratos Quase Inocentes pelo próprio Carlos Eugênio, pela crítica de arte Aracy Amaral, pelo historiador Carlos Lemos e pelo cineasta Jean-Claude Bernardet. Onze anos mais tarde, uma nova exposição seria feita na Pinacoteca do Estado, intitulada também Retratos Quase Inocentes (FIGURA 10).

Menção especial merece a coleção de fotografias de Militão Augusto de Azevedo. São mais de 12.000 retratos produzidos entre 1862 e 1885 nos 
5. Para a conservação e restauração de filmes contamos sempre com o laboratório da Cinemateca Brasileira. Para as fotografias tivemos auxílio eventual da FUNARTE, até que a então técnica de museu do SVDHICO especializou-se no tratamento de fotografias. Hoje, atuando no Laboratório de Conservação e Restauração do Museu,temos condições de dar às fotografias o tratamento rotineiro de limpeza e recuperação que antes buscávamos fora da instituição. estúdios Carneiro \& Gaspar e Photographia Americana. Localizados na antiga Rua da Imperatriz (atual XV de Novembro) por eles passou grande parte da população. Entre moradores e pessoas ilustres, seus manuscritos identificam figuras como o barbeiro, o vendedor de jornal, o alfaiate, a engomadeira, o tabelião, atores e cantores de companhias de teatro, escravos, políticos, "capitalistas", clérigos, militares e profissionais liberais da época (FIGURA 11). Fazem parte desta coleção os registros fotográficos mais antigos da cidade de São Paulo e o conhecido álbum comparativo, que mostra aspectos urbanos da capital paulista entre 1862 e 1887, e que foi pioneiro neste estilo que viraria moda no século XX. Raros registros da cidade de Santos e da construção da Railway (Santos-Jundiaí) também podem ser encontrados.

Serviço conta ainda com coleções, que contemplam as histórias familiares e seus registros dos ritos de passagem e de parentes da família nuclear e extensa, como é o caso da coleção Pacheco e Chaves, que reúne documentação textual, álbuns fotográficos e fotografias avulsas. Outro importante núcleo é o de álbuns produzidos nas primeiras décadas do século XX por Luiz Gonzaga de Azevedo, filho do fotógrafo Militão (5 álbuns com ampliações fotográficas). Em 2002, o Museu Paulista recebeu a doação da família Jafet, reunindo documentos em diversos suportes - imagens, textos e tridimensionais. A coleção da Família Jafet é exemplar da trajetória de famílias imigrantes que lograram sucesso social e econômico na sociedade paulistana. Os conjuntos fotográficos referem-se às inúmeras viagens realizadas para o exterior (Europa e Estados Unidos), festividades familiares e documentários de espaços de trabalho ou da trajetória do patriarca da família (centenas de imagens reunidas em 11 maletas originais de slides, 19 álbuns e 2 filmes; 43 peças entre roupas, acessórios de indumentária, móveis, equipamentos audio-visuais, apetrechos de escritório e 26 pastas contendo folhetos turísticos, material do Rotary Club, programas culturais, manuais de utensílios domésticos, revistas, recortes de jornais) (FIGURAS 12, 13). Integra ainda esta coleção um conjunto de filmes $16 \mathrm{~mm}$ com características semelhantes, sendo de maiores proporções o aspecto público dos eventos registrados - bodas de prata, funeral ${ }^{5}$.

Conta-se também com álbuns de retratos anônimos, comprados em antiquários e sebos. Neste caso, muito embora não seja possível o levantamento dos dados referentes aos retratados e proprietários, a organização formal das imagens, bem como as características temáticas ou dos suportes guardam interesse para a pesquisa. Nessa linha vale a pena mencionar um álbum de fotografias doado ao museu e que foi adquirido de um vendedor ambulante das ruas do Rio de Janeiro. O álbum anônimo, mas claramente montado por particular (com notas manuscritas e a presença de diferentes agentes), reúne exclusivamente fotografias de casais no dia do casamento. $\bigcirc$ álbum encontra-se em precário estado de conservação, mas sua organização temática sugere hipóteses no mínimo curiosas: quem seriam os proprietários dos álbuns? Padrinhos que resolveram fazer um álbum de recordações de todos os seus casais apadrinhados?

Outro caso que se soma a este pela inusitada trajetória de integração ao acervo do Museu Paulista é o de um álbum raro, datado de 1878, reunindo retratos fotográficos no formato cartão de visita, originais em albumina, de celebridades européias. Este álbum foi oferecido para aquisição por uma senhora que o ganhara de seu esposo, catador de papéis, que por sua vez havia encontrado o referido álbum em uma das inúmeras lixeiras de um bairro nobre de São Paulo (FIGURA 14). Estas e outras histórias são registradas e têm importância para o entendimento 


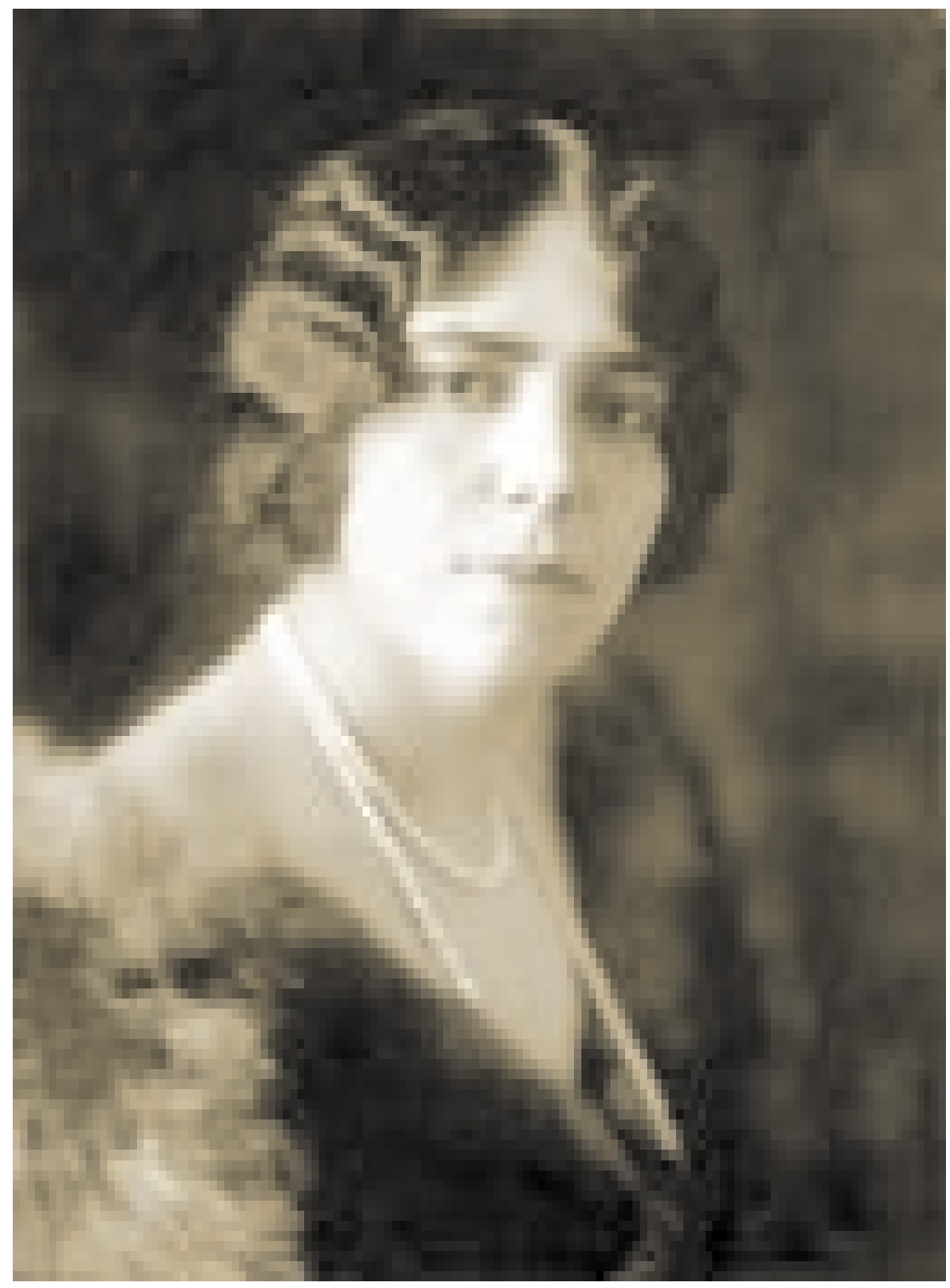

FIGURA 9 - Stela Penteado da Silva Prado, 1936, fotografia p\&b, gelatina, 19,7 × 14,4 cm. Coleção Orôncio Vaz Arruda. Acervo Museu Paulista da USP. Reprodução de Hélio Nobre. 


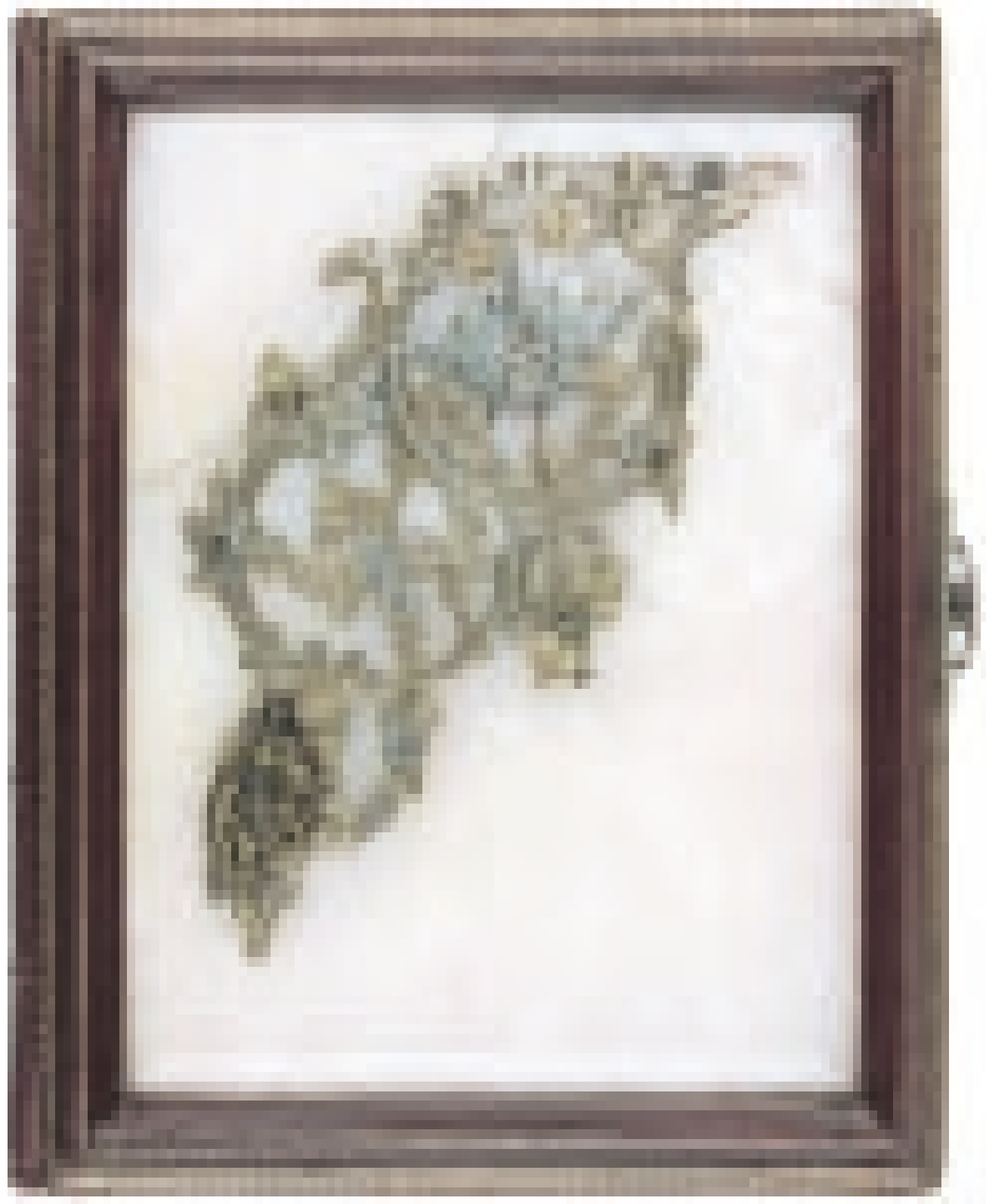

FIGURA 10 - Álbum com capa de marroquim em alto relevo, incrustação de alabastro e aplicação metálica, 33,5 × 25,5cm, c. 1900. Coleção Carlos Eugênio Marcondes de Moura. Acervo Museu Paulista da USP. Fotografia de Hélio Nobre. 


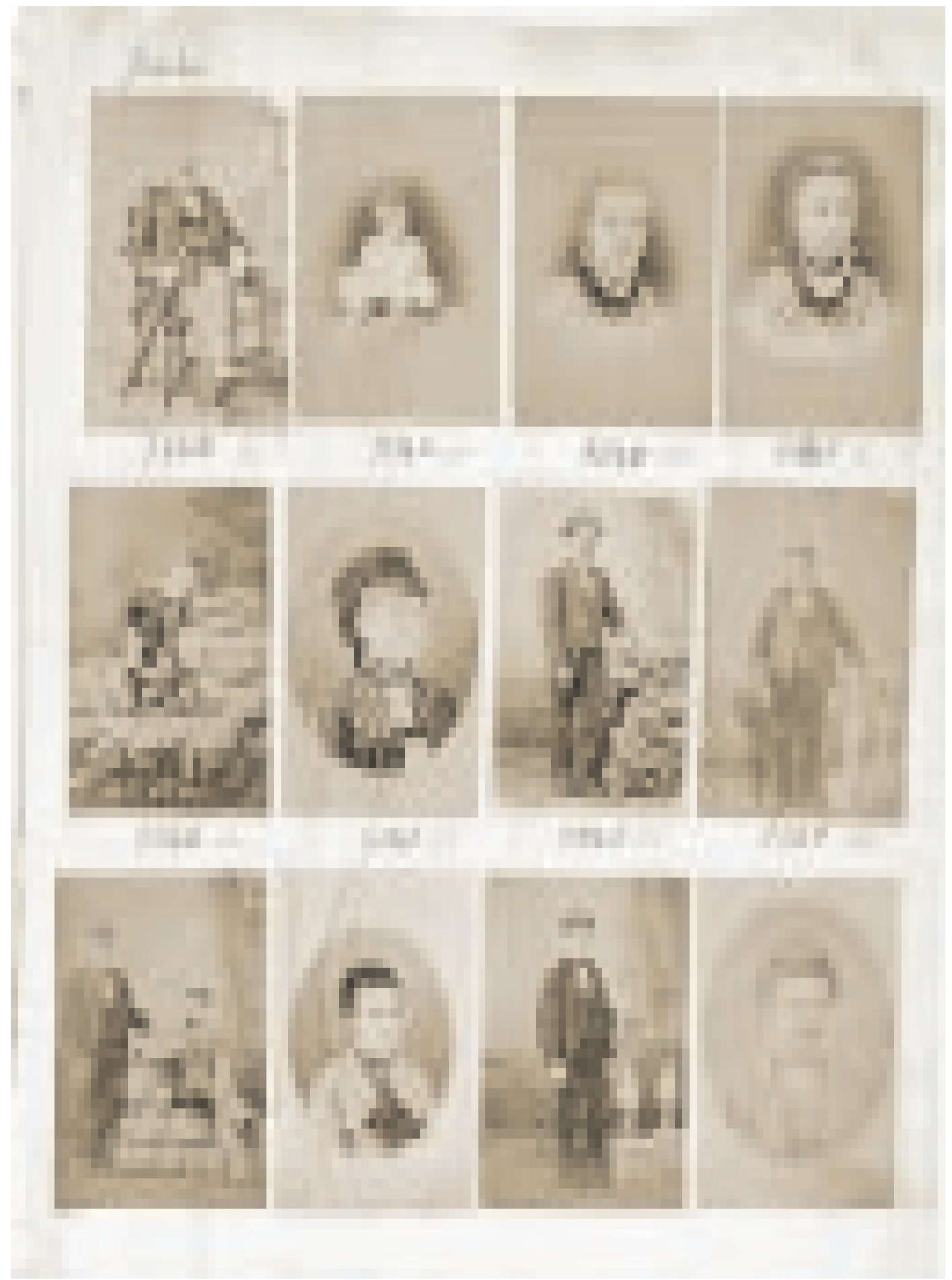

FIGURA 11 - Página do álbum do estúdio Photographia Americana, 1879-1885, retratos, albumina sobre papel, $33,5 \times 24,5 \mathrm{~cm}$. Coleção Militão Augusto de Azevedo. Acervo Museu Paulista da USP. Reprodução de Hélio Nobre. 


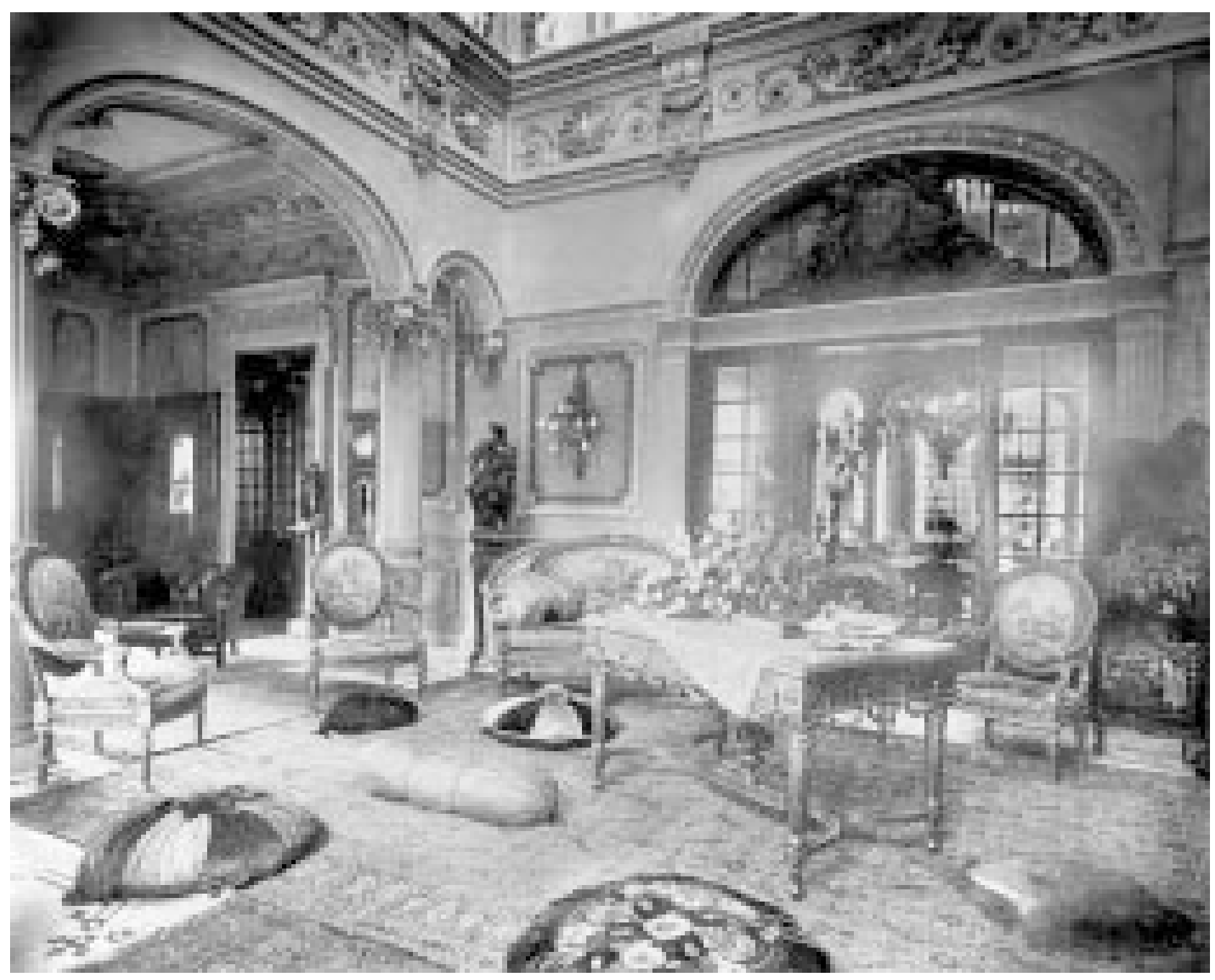

FIGURA 12 - Fotografia de uma das salas de visita do palacete Jafet. Álbum Palacete Bazilio Jafet. 1928. São Paulo, $32 \times 40 \mathrm{~cm}$. O palacete fica na Rua Bom Pastor, n. 730, esquina com a rua Patriotas, dando seus fundos com o Parque da Independência. As fotografias mostram os ambientes da residência com decoração e mobília da época de sua inauguração. Coleção família Jafet. Acervo Museu Paulista da USP. Reprodução de Hélio Nobre. 


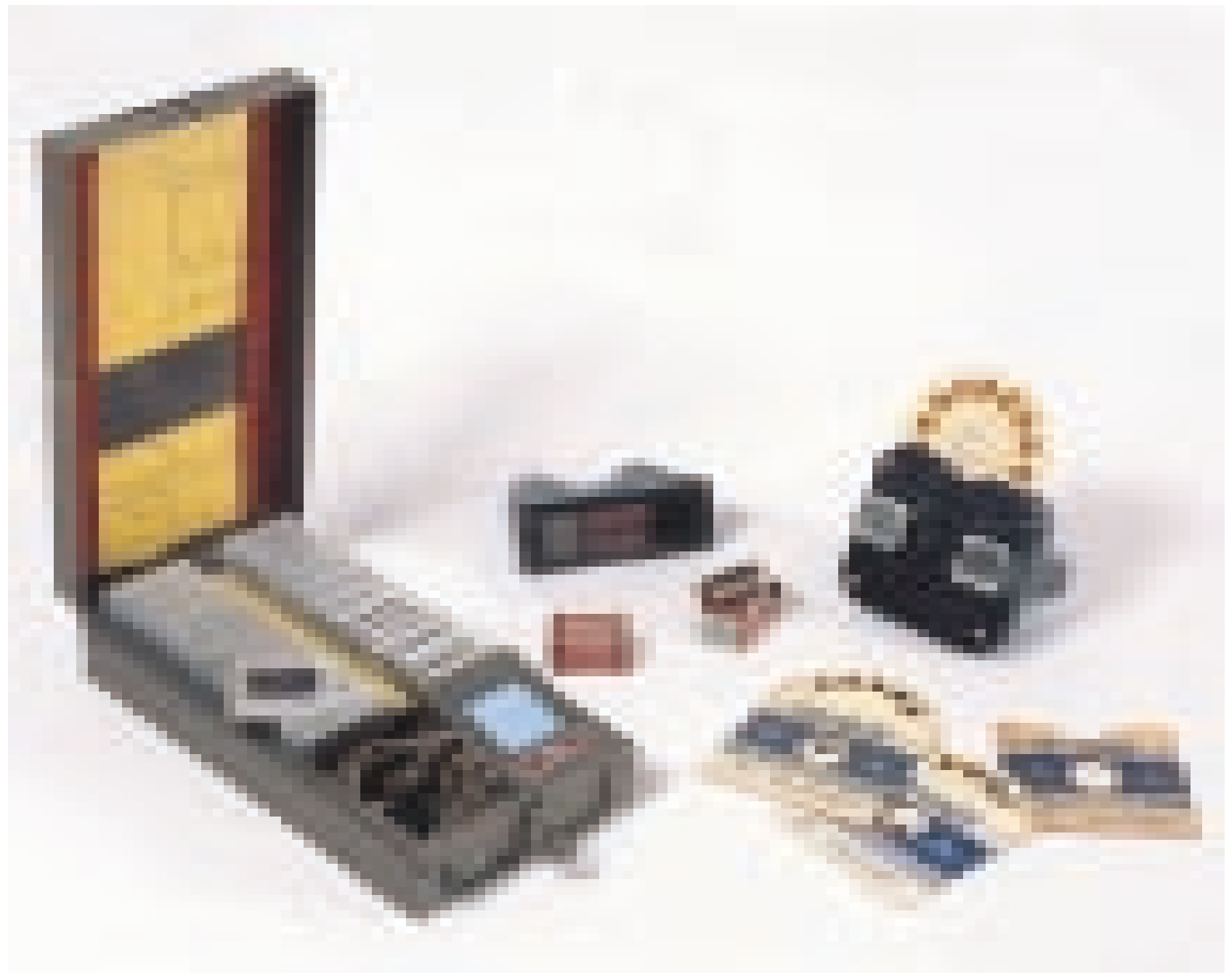

FIGURA 13 - Slides de São Paulo e Guarujá, em molduras de metal, acondicionados em caixa de metal com leitora elétrica Viewer Slide File Model n. 155 - Fodeco - 115 volts - 7 watts, made in USA by Technical Devices Corporation, Roseland, NJ; Tele - visex com três discos e leitora estereoscópica tipo Tru-vue acompanhada de filmes. Coleção família Jafet. Acervo Museu Paulista da USP. Fotografia de Hélio Nobre. 


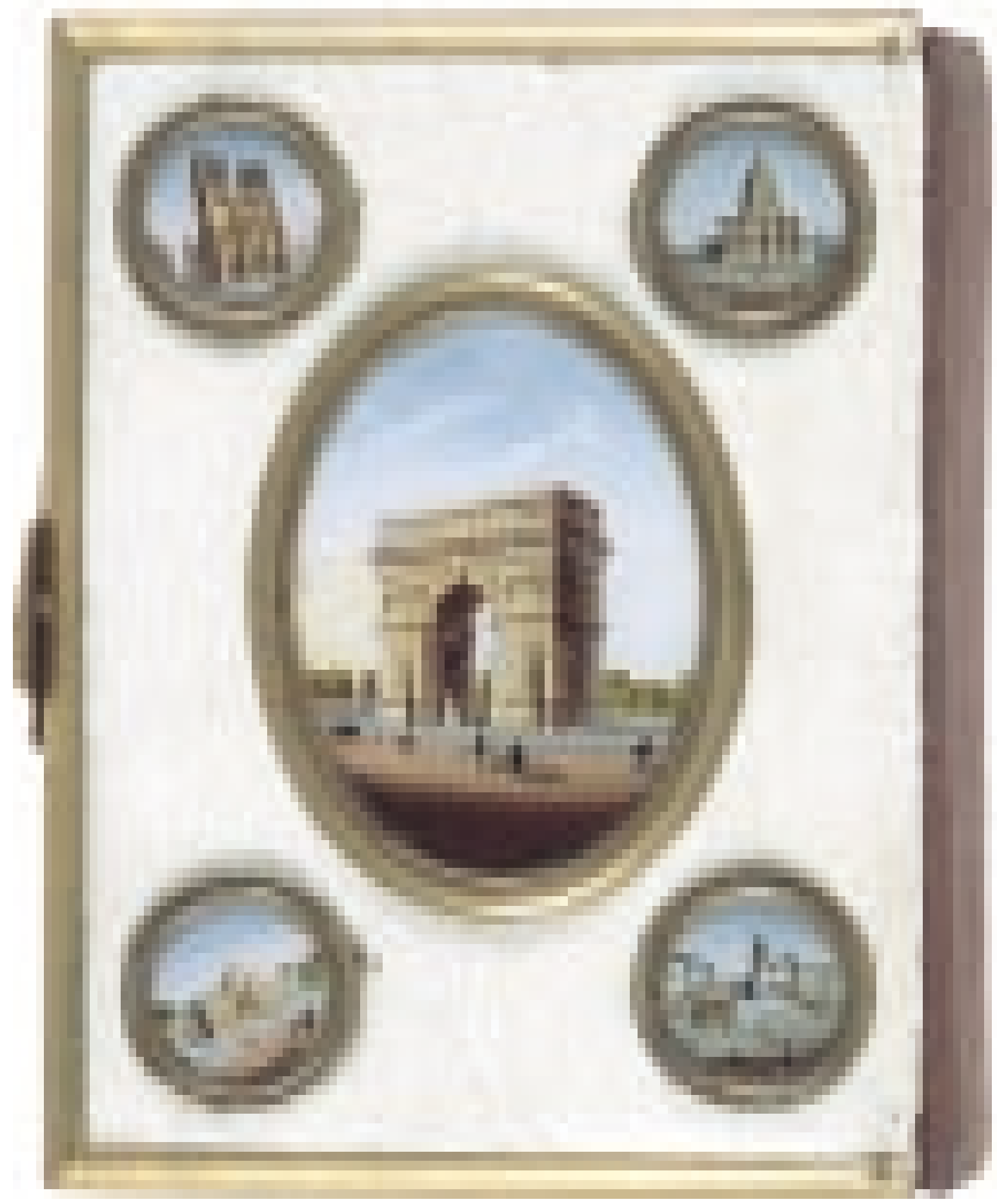

FIGURA 14 - Álbum de personalidades com 46 retratos albuminados no formato cartão de visita, $16 \times 12,5 \mathrm{~cm}$, legendas manuscritas em português, Paris, 1875. Adquirido de Laura Henrique Santos. Acervo Museu Paulista da USP. Fotografia de Hélio Nobre. 
do circuito da imagem, chamando a atenção para a sua qualidade de objeto, que é apropriado, descartado e reciclado (FIGURAS 15-17).

No que concerne às imagens urbanas (outra vocação que identificamos na iconografia preexistente no acervo centenário), procurou-se fazer uma cobertura sistemática de cartões postais, privilegiando a cidade de São Paulo. Esta é uma tipologia documental pouco encontrada em museus e arquivos, mas de imenso potencial para os estudos de história urbana, da arquitetura e, sobretudo, de representações sociais urbanas, temática que se articula à linha de pesquisa História do Imaginário. Hoje, o SVDHICO conta com expressiva coleção referente a cidades brasileiras, especialmente ao Estado e à cidade de São Paulo, produzida entre 1900 e 1950. De um total de cerca de 2.000 cartões, pelo menos 1/3 referese à capital paulista (FIGURA 18).

No início de 2001 integrou-se ao nosso acervo ${ }^{6}$ a coleção de fotografias urbanas e de documentos textuais da editora Fotolabor. A Fotolabor, que pertenceu ao Sr. Werner Haberkorn (Alemanha, 1907-SP, 1997), foi uma das mais ativas editoras de cartões postais referentes à cidade de São Paulo nos anos 50, além de prestar também serviços publicitários (CARVALHO; LIMA, 2002) (FIGURA 19).

No caso da documentação de obras de engenharia e arquitetura, típica função atribuída à fotografia no século XIX, destacam-se as fotografias da Estrada de Ferro Santos-Jundiaí (1 867)7, da construção do Reservatório de Água da Cantareira (1893) ${ }^{8}$, da construção do edifício que abriga o Museu Paulista ( 1890$)^{9}$, e a coleção de negativos do fotógrafo Dana Merrill ( 189 negativos em vidro e acetado, produzidos entre 1909 e 1910), norte-americano que documentou a construção da ferrovia Madeira-Mamoré, no meio da floresta no atual Estado de Rondônia. Essas coleções permitem vislumbrar não apenas o lugar da técnica no século XIX e as novas formas de interação do homem com a máquina, mas, igualmente importante, os sentidos que a imagem logrou constituir, pondo em pauta quais funções cumpriria a fotografia neste contexto - a comparação, por exemplo, das imagens de Militão da São Paulo Railway (Santos-Jundiaí) com os registros de Dana Merrill da ferrovia Madeira-Mamoré (Rondônia), quase 50 anos mais tarde, demonstra como a fotografia afastou-se do modelo pictoricamente equilibrado, limpo e ordenado, aplicado às representações dos grandes feitos tecnológicos para pôr em cena as tensões entre máquinas, floresta e homens de diferentes grupos sociais, étnicos e profissionais (CARVALHO, 2000, p. 46-48; CARVALHO; LIMA, 2000).

investimento na aquisição dessas coleções decorre da escolha da fotografia como um dos focos principais de atuação curatorial. Ao lado de mudanças nos procedimentos de aquisição de coleções, nossa reflexão sobre a imagem caminhou no sentido de compreender seus atributos específicos. Assim, uma parte dos trabalhos de pesquisa e curadoria voltou-se para a identificação e análise histórica dos aspectos formais da fotografia.

Ao SVDHICO foram incorporados os resultados de pesquisa acadêmica desenvolvida por seu corpo de pesquisadores na montagem de vocabulários controlados aplicados às paisagens urbanas. Em projeto integrado de mestrado, as historiadoras Solange Ferraz de Lima e Vânia Carneiro de Carvalho analisaram um conjunto de 1.600 fotografias da cidade de São Paulo, entre os anos de 1860 e 1954. Objetivo era demonstrar como as noções de cidade eram construções concretas e não apenas sentidos impalpáveis inferidos da presença de certos conteúdos. Com descritores formais aplicados a cada fotografia foi
6. Toda documentação doada ou adquirida pelo Museu conta com laudos técnicos produzidos pela equipe de curadores que avaliam as peças oferecidas tanto no seu aspecto físico, de conteúdo e pertinência com as linhas de pesquisa da instituição. Quando valores monetários elevados estão envolvidos, como no caso de compras, pareceristas ad boc são consultados.

7. Autoria de Militão Augusto de Azevedo.

8. Autoria de P. Doumet.

9. Autoria de Guilherme Gaensly. 
possível derivar tendências visuais presentes no conjunto analisado. Esse tipo de procedimento iria fundamentar os futuros trabalhos desenvolvidos com curadoria histórica e fotográfica no SVDHICO (CARVALHO; LIMA, 1997). Essa abordagem dos recursos visuais da imagem não se restringe a simplesmente criar meios de acesso à documentação, o que reduziria um Serviço que tem como objetivo integrar tratamento documental à produção de conhecimento a um mero depósito de imagens e textos.

A pesquisa sobre o uso da fotografia na configuração do projeto de exposição histórica idealizado para o Museu Paulista por Affonso de E. Taunay foi uma oportunidade para enriquecer os estudos sobre a problemática do imaginário urbano, que já vinha sendo abordada nos mestrados articulados de Vânia Carvalho e Solange F. de Lima. A pesquisa resultou em uma exposição - São Paulo antigo, uma encomenda da modernidade, um vídeo didático (RUIZ et al., 1993), um artigo publicado nos Anais do Museu Paulista (CARVALHO; LIMA, 1993a) e apresentação de comunicação no V Congresso de História da Arte (CARVALHO; LIMA, 1993). $\bigcirc$ estudo e sua divulgação, abarcando do espaço museológico aos tradicionais canais da academia, permitiram que se tivesse uma noção mais concreta do trabalho de curadoria e do papel do historiador em um museu de história - a atividade em equipe, iniciada com a co-autoria na curadoria histórica e na divulgação acadêmica, e que se completou com os trabalhos junto às equipes responsáveis pela exposição e pelo vídeo. A documentação mobilizada integrava não só o acervo iconográfico do Museu Paulista, como havia sido objeto de exploração cultural anterior - a exposição histórica projetada por Taunay em 1922 (TAUNAY, 1937). Assim, a pesquisa se viu revestida de funções metalingüísticas, pois englobara não só um

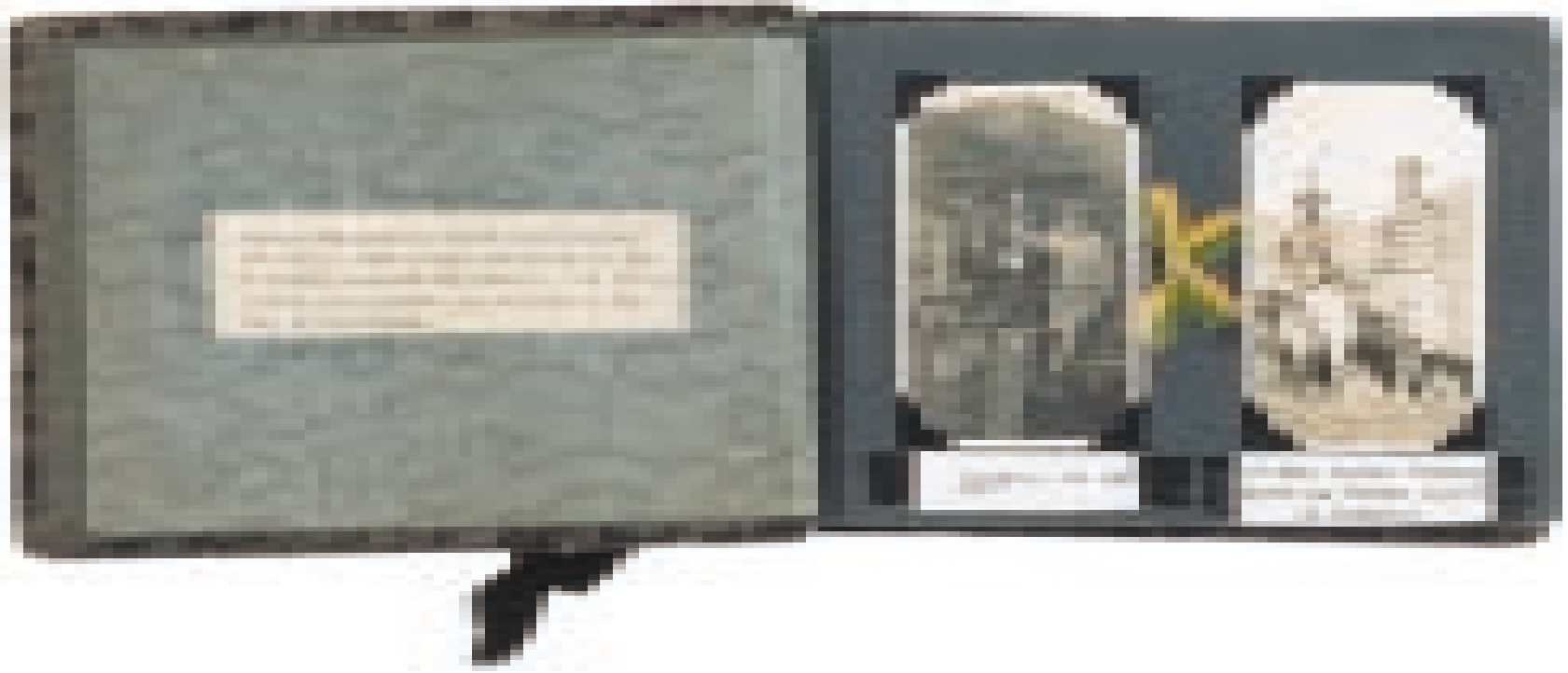

FIGURA 15 - Álbum com 107 fotografias originais reunindo registros da Revolução de 1932. Coleção Juvenal Andrade de Souza Barros. Acervo Museu Paulista da USP. Fotografia de Hélio 

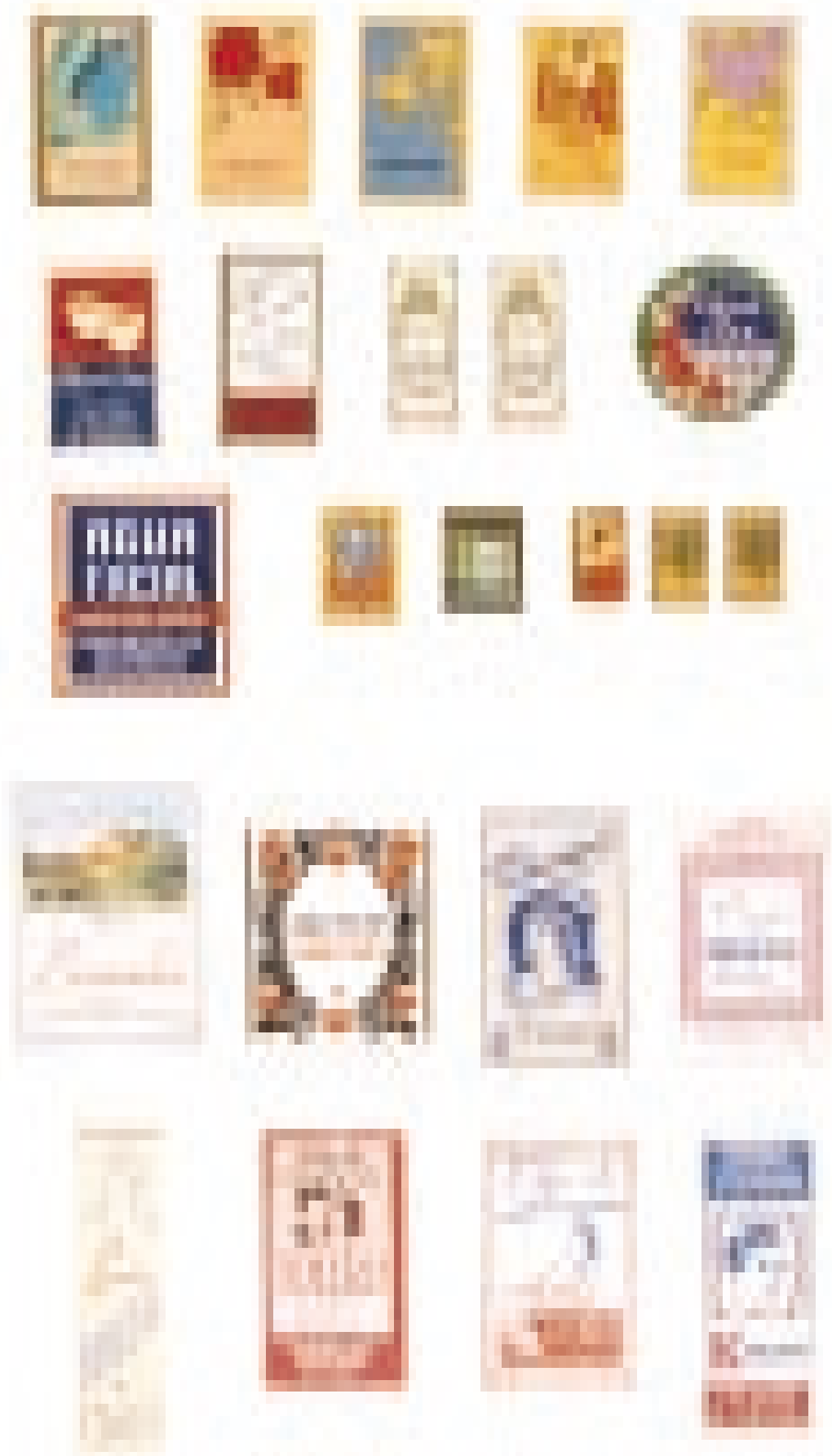

FIGURA 16 - Prancha de rótulos, 1900-1920. Coleção Egydio Colombo Filho. Acervo Museu Paulista da USP. Reprodução de Hélio Nobre. 
conjunto iconográfico, mas o seu uso no mesmo espaço museológico. Ela ajudou a entender melhor o contexto histórico e ideológico de formação do Museu Paulista no século XX e de suas coleções.

Com a atividade de curadoria do acervo iconográfico percebeu-se o potencial inerente ao banco de imagens informatizado para os estudos, que procuram demonstrar como a forma é parte estruturante e, portanto, indissociável de suas funções sociais. A história da visualidade compreende a imagem como parte da prática social, sendo comprometedora a dissociação existente entre a natureza histórica das imagens e os sistemas de documentação, reduzidos a descrições genéricas (CARVALHO; LIMA, 2000, 2000a, 2002). Instituições como os museus, que gerenciam acervos iconográficos, são lugares privilegiados para a implantação de bancos de dados, que contemplem a especificidade da imagem, especificidade que reside em grande parte no fato de ela ser um objeto visual. Atualmente, os banco de imagens são capazes de recuperação de imagens cores, texturas ou mesmo fisionomias. Mas, como já apontamos (CARVALHO; LIMA, 2000),

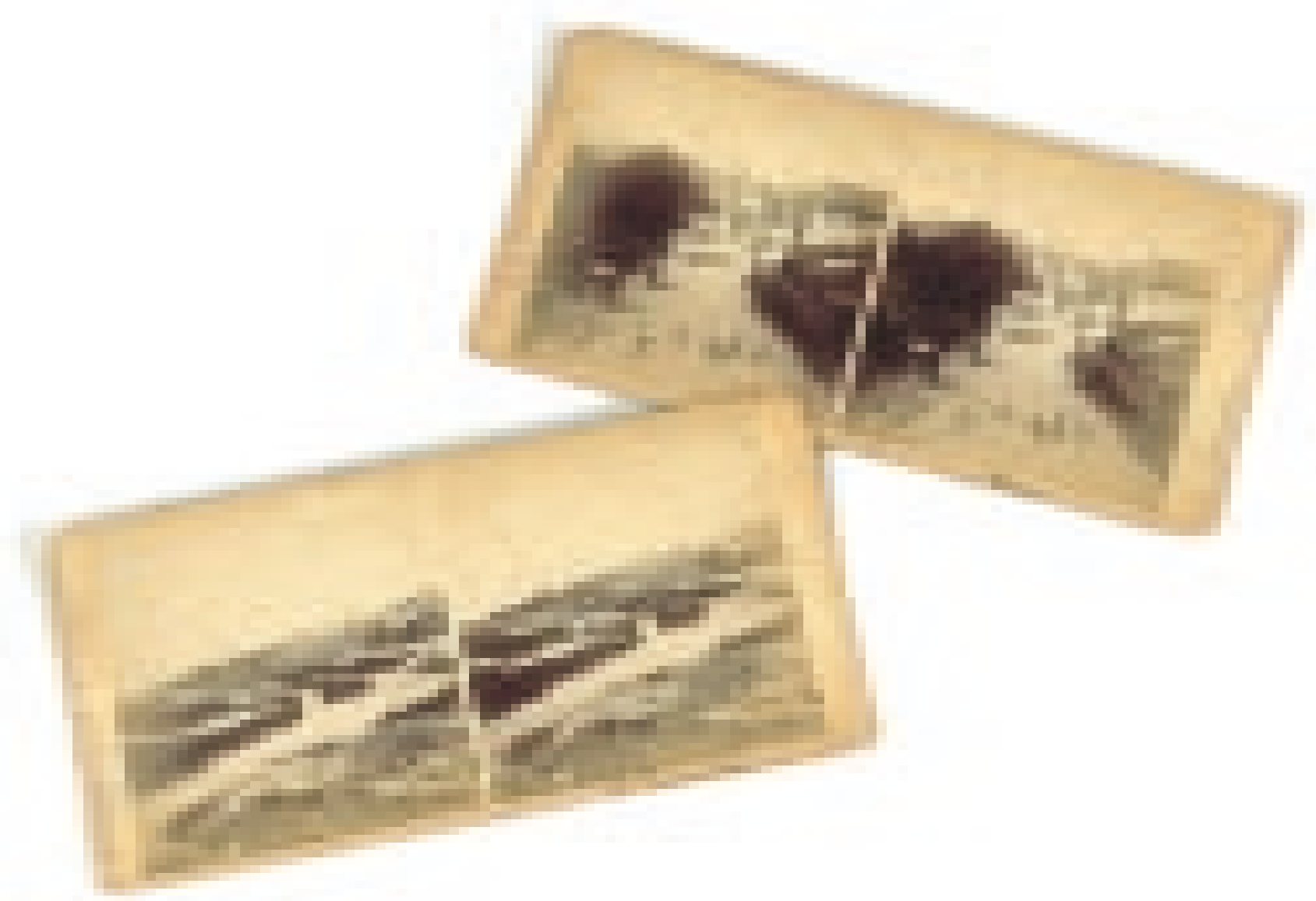

FIGURA 17 - Rio Tamanduateí e Piques, São Paulo, déc. 1890. Fotografias estereoscópicas, albumina, do estúdio Photographia Renouleau. Coleção Aracy Amaral. Acervo Museu Paulista da USP. Fotografia de Hélio Nobre. 


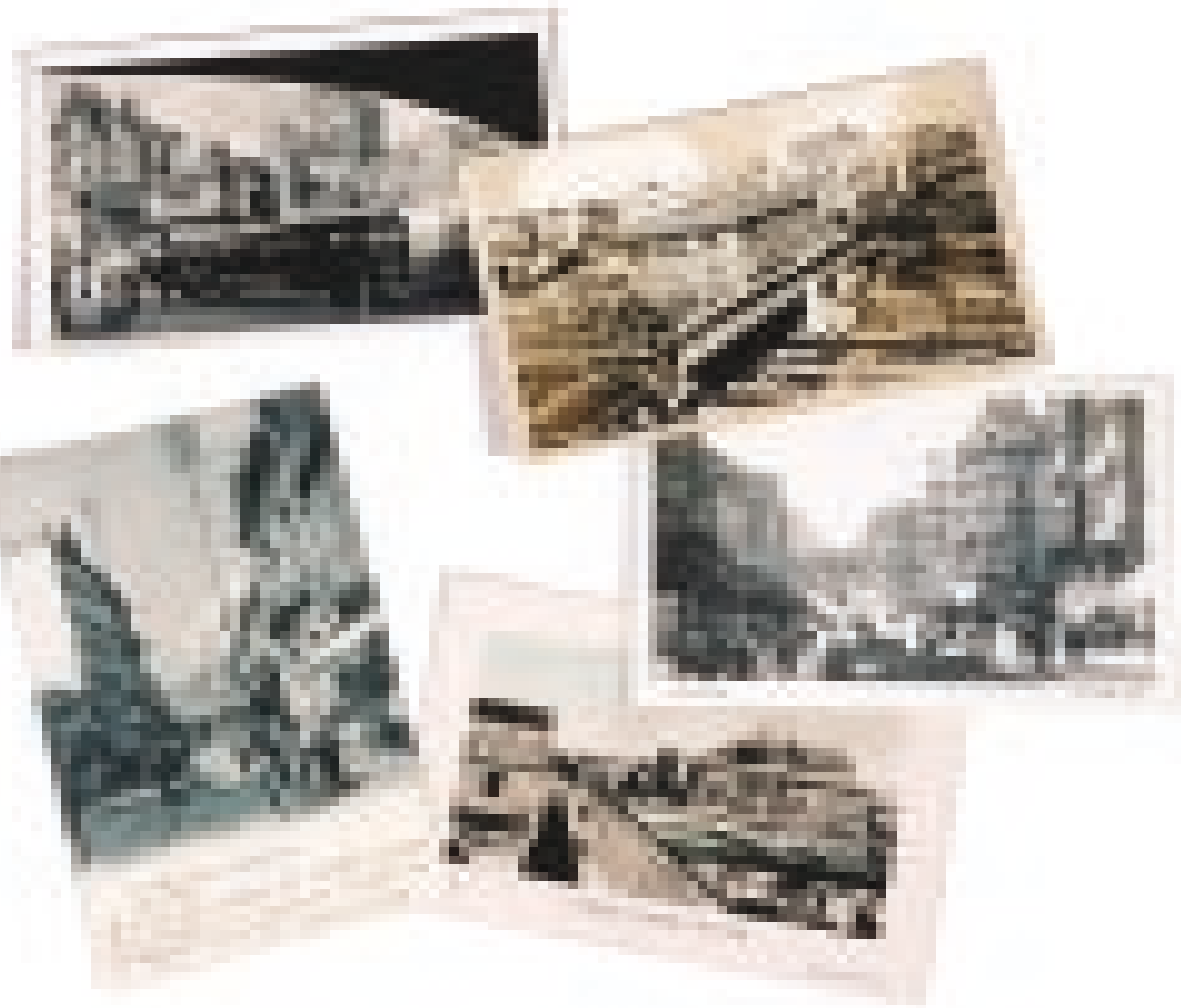

FIGURA 18 - Anhangabaú, viaduto do Chá, Rua XV de Novembro e Avenida São João. Coleção cartões postais da cidade de São Paulo. Acervo Museu Paulista da USP. Fotografia de Hélio Nobre. 


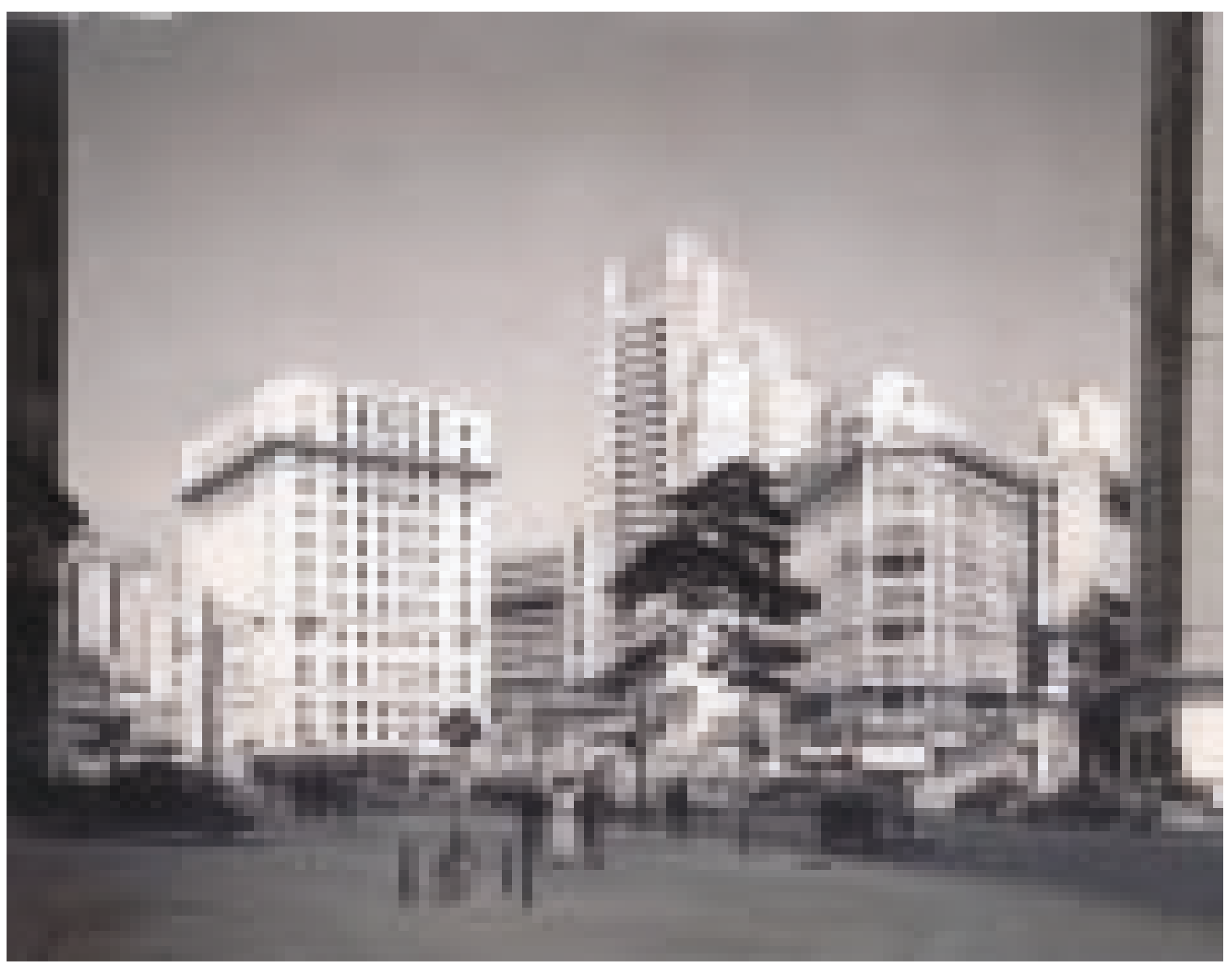

FIGURA 19 - Início da Avenida 9 de Julho. Fotografia de Werner Haberkorn, p\&b, gelatina, 18 $\times 24 \mathrm{~cm}$. Coleção Werner Haberkorn. Acervo Museu Paulista da USP. Reprodução de Hélio Nobre. 
curiosamente, os programas que permitem tal sofisticação na busca de imagens não foram incorporados aos arquivos e museus. Aos pesquisadores das ciências humanas cabe fornecer os elementos necessários para que o repertório formal das imagens possa ser compreendido e utilizado pedagogicamente em experiências que ultrapassem o circuito da academia. A demanda hoje por imagens deve vir acompanhada de um esforço de crítica da imagem. Acreditamos que a crítica não pode dispensar a compreensão dos elementos formais que constituem essa imagem.

Com quase nenhuma identificação de seus retratados, as fotografias de Militão são um bom exemplo da necessidade de uma metodologia, que incorpore a análise morfológica da imagem. Nesta coleção imensa de desconhecidos chama a atenção a retórica corporal que o século XIX produziu dentro do estúdio, cercando seus personagens com adereços, objetos decorativos, painéis de fundo, cabelos, roupas e posturas corporais considerados dignos de exposição pública. $\bigcirc$ estudo dos sentidos cabe ao pesquisador que, munido de problemáticas específicas, mobiliza os atributos formais para entender como estes foram interpretados pela sociedade, não apenas no momento de sua produção, mas nos diferentes modos de apropriação e circulação da imagem. No entanto, o banco de dados sobre a coleção Militão passou a oferecer aos seus usuários dados formais primários que deveriam ser posteriormente trabalhados por eles (CARVALHO; LIMA, 1997).

Ao mesmo tempo, as experiências com os acervos do SVDHICO têm alimentado estudos que confluem na pesquisa Retrato e cenografia: imagem e personagem. $\bigcirc$ projeto aborda os aspectos materiais da construção das noções de individualidade nos retratos fotográficos produzidos em estúdio durante a segunda metade do séc. XIX e primeiras décadas do século XX. Uniram-se as duas extremidades da curadoria, a desacreditada "pesquisa documental" ou a mais ainda desacreditada "catalogação de acervo" com a pesquisa acadêmica. Uma situação de retroalimentação que tem beneficiado pesquisadores de várias áreas, bem como usuários do acervo para fins culturais, comerciais ou pedagógicos.

primeiro produto tridimensional com a coleção de retratos de Militão foi a exposição São Paulo nas lentes de Militão, inaugurada em $1997^{10}$. Um painel com cubos giratórios, contendo retratos em suas faces, permitia que o visitante percebesse as poses mais recorrentes. Ao girar os cubos os visitantes poderiam colocá-los em posições variadas e acabariam, orientados por cores, chegando aos conjuntos. Graças à indexação informatizada dos descritores, aprofundou-se a análise dos padrões visuais no retrato. Buscou-se, de uma lado, estabelecer as permanências formais na trajetória da representação figurativa do gênero retrato na pintura desde o século XVII, e de outro, encaminhar questões concernentes ao circuito que estes retratos cumprem como parte da dinâmica de reprodução das relações sociais. Se a análise morfológica, que pôs em evidência os aspectos formais, relevando a especificidade do pensamento plástico, pautouse nas postulações e procedimentos metodológicos de Francastel ( 1965) e Panofsky (1979, 1º ed. de 1939), a genealogia e apropriações sucessivas das permanências formais encontraram nos estudos de Burke (2001) novos caminhos para a abordagem do problema da representação pública do indivíduo. Por fim, as questões envolvendo a materialidade do objeto fotográfico - o retrato - e de seu circuito, encaminhadas a partir dos trabalhos de Brilliant ( 1991 ) e Meneses (2003, p. 131-151), podem ser sintetizadas no conceito de retratística como campo que engloba não só a produção do retrato, mas também as funções sociais
10. A exposição "São Paulo nas Lentes de Militão Augusto de Azevedo" foi aberta ao público em maio de 1997. Curadoria de Solange Ferraz de Lima e Vânia Carneiro de Carvalho. Pesquisa e Documentação de Regina Teles, Cláudia Moi, Renata Garbellini, Montserrat Moreno. Concepção visual e Desenho gráfico deAna Helena Curi, Cláudia Warrak (designer), Fábio Montenegro e Fernando Rodrigues (arquiteto). 
11. Direção artística, edição e trilha sonora de GavinAdams; direção científica e roteiro de Solange Ferraz de Lima eVânia Carneiro de Carvalho; produção do Museu Paulista da USP,Fundo de Pesquisa do Museu Paulista e Espaço Digital;finalização da Espaço Digital; equipe de produção: Alan Renato Chagas, Alessandro Sartori, Anderson de Cácia Almeida, Bruno da Silva Reis, Dani Toda, Daniel Márcio Reis, Geosvaldo Braz de O. Santos Júnior, Luciano Antônio Beraldo, Luiz Eduardo Lopes Correa, Marcos Mendes, Robson Sartori, Ronaldo Alves de Lima,Saulo Simão Rocha Moraes, Sérgio Jacobina, Shirley Ribeiro da Silva e Tatiana Vasconcelos dos Santos.

12. Curadoria científica de Solange Ferraz de Lima e Vânia Carneiro de Carvalho; curadoria artística de Gavin Adams; projeto cenográfico de Marieta Ferber;programa para instalação Olho Cíclico de Carlos Freitas; equipe de trabalho: Shirley Ribeiro da Silva, Mayra Tiemi Yonashiro Saito, Frederico Hila; projeto educativo de Denise Peixoto. Apoio do Fundo de Pesquisas do Museu Paulista, Fundo da Pró-Reitoria de Cultura e Extensão da USP. concretizadas nas múltiplas trajetórias que ele cumpre ao inserir-se na dinâmica social (a lembrança, o presente, a presença no álbum, a referência na conversa, nas missivas, etc.), tal como nos ensina Marcia Pointon (1993). Igualmente, as múltiplas apropriações do objeto fotográfico, dada a autonomia que ganha como produto da reprodutibilidade técnica, gerando sentidos específicos a cada contexto em que acaba por integrar-se, deveriam ser consideradas mais importantes para o historiador do que a vinculação indicial com a realidade da produção fotográfica, como demonstra Meneses ao explorar a mitologia criada em torno da fotografia do miliciano espanhol retratado por Capa (MENESES, 2003, p. 131 -151). Aqui pisa-se o solo movediço da recepção, muitas vezes evitado pelos historiadores, dada a escassez de fontes que permita avançar nas hipóteses de uso e reciclagens.

Os resultados parciais desta fase da pesquisa foram divulgados no Primer Congreso sobre imágenes e investigación social (México, DF, 2002) (CARVALHO; LIMA, 2002). O desenvolvimento da pesquisa mobilizará, a partir deste momento, as demais coleções de retratos que integram o Acervo do Museu Paulista, avançando na cronologia. Pretende-se verificar rupturas e permanências nas configurações cenográficas e performáticas ocorridas na retratísticas do século XX, com base principalmente nas coleções Carlos Eugênio Marcondes de Moura e Orôncio Vaz Arruda, que reúnem, juntas, mais de três mil imagens oriundas de diversos estúdios fotográficos brasileiros e do exterior.

Outra experiência nesta direção nasceu do interesse do artista plástico Gavin Adams em associar as experiências estéticas produzidas a partir de imagens em movimento à problemática do retrato - padrões de pose, produção seriada e construção de identidades sociais. A partir do vídeo-ensaio Poses do 19 (ADAMS et al., 2002) ${ }^{11}$, e da pesquisa Retrato e cenografia: imagem e personagem nasceu 0 projeto Cultura Visual: entre Arte e História ${ }^{12}$. Sua natureza interdisciplinar aproxima duas áreas - artes plásticas e história da cultura material. O objetivo é articular as problemáticas históricas ligadas à fotografia oitocentista com conceitos e linguagens oriundos das artes plásticas, através de dispositivos visuais e tridimensionais tratados em ambiente expositivo ou mídias audiovisuais no espaço de um museu de história.

O projeto possui vários módulos de natureza híbrida (científica, artística e pedagógica):

- Módulo-exposição Olho Cíclico-Animatoscópio: trata-se de uma instalação onde o foco é um banco de dados da coleção de retratos de Militão. ○ usuário monta sua seleção a partir de um mapa virtual de 2.500 retratos, organizados por regiões tipológicas (p.ex., homem em pé com coluna, homem em pé com cadeira, homem sentado, mulher em pé com coluna, casais, crianças, etc.) e vê, em tempo real, a seqüência selecionada. O usuário entra em contato, na prática, com questões da organização e estudo de uma coleção, desvelando discursos e artifícios da prática fotográfica que gerou os cartões de visita:

- Módulo-exposição de artistas convidados: visando a ampliar o diálogo entre a curadoria histórica e as artes plásticas, a apresentação da instalação sobre os retratos de Militão está vinculada à apresentação paralela de obras de artistas convidados, cujas investigações artísticas têm se alimentado da pesquisa em coleções e acervos históricos.

- Módulo-seminário Cultura Visual: entre Arte e História: o vídeo, a instalação e as obras dos artistas convidados servirão de matéria-prima para discussões acadêmicas em torno do uso da linguagem das artes plásticas em exposições históricas, o potencial de exploração artística de acervos históricos, 
ou ainda, as possibilidades de difusão, em um museu histórico, da experiência interdisciplinar; em outras palavras, a interação entre obra e público. As mesas de seminário pretendem aproximar historiadores da cultura, historiadores das artes, artistas, antropólogos e educadores.

- Módulo-catálogo Cultura Visual e Curadorias Interdisciplinares: o catálogo reunindo apresentação das obras dos artistas, os textos dos seminários e a transcrição do debate serviria de referência para novas discussões em uma área tão explorada como espetáculo, mas carente de abordagens críticas e interdisciplinares. Seria também um instrumento importante para estabelecer novas parcerias no exterior e para inaugurar o programa de artista-residente em museus.

- Módulo-estudo de Recepção do vídeo Poses do 19 e elaboração de estratégias educativas para a percepção de imagens ${ }^{13}$ : com duas versões levemente alteradas com a aplicação ou subtração de textos que enfatizam os módulos conceituais da seqüência de imagens apresentadas, iniciamos em março de 2003 a aplicação de questionários aos estagiários da instituição, grupos de estudantes universitários, grupos de curso para a terceira idade e alunos de pós-graduação. Durante o ano de 2004, o resultado da pesquisa de recepção deverá fornecer subsídios para a elaboração de instrumentos pedagógicos de mediação entre professor e aluno para a exploração do vídeo Poses do 19 em sala de aula.

Pretende-se demonstrar que o artista plástico tem no Museu um vasto território documental e uma produção científica que merece ser apropriada, e que a curadoria histórica não pode hoje prescindir da criatividade do artista para a realização plástica de problemáticas desenvolvidas nos moldes textuais da academia.

Se durante o mestrado foi possível aos pesquisadores do SVDHICO articular procedimentos e metodologias de análise de imagens à atividade curatorial concernente à catalogação de imagens urbanas, no doutorado as responsabilidades curatoriais alcançaram outro patamar. A pesquisa documental realizada para o desenvolvimento da tese de doutorado Ornamento e Cidade ferro, estuque e pintura mural - 1870 -1930 (LIMA, 2002) acabou por gerar um projeto que se encontra em fase inicial. Trata-se do projeto Ornamentação arquitetônica - cidade e regimes visuais: a pintura mural de interiores de Oreste Sercelli, um estudo de caso que mobiliza a coleção de documentos e objetos pertencentes a Oreste Sercelli ${ }^{14}$ - pintor/decorador italiano, formado pela Escola Profissional de Artes Industriais e Decorativas de Florença, que imigrou para o Brasil no final do século XIX e aqui desenvolveu a sua trajetória profissional. A coleção Oreste Sercelli é preciosa por preservar documentos de natureza variada que registram o processo de trabalho de um artesão no início do século XX. Fato raro em um país com pequena tradição na guarda da memória de seu universo de trabalho artesanal. Esses núcleos de documentos, que já alimentaram estudos como o de Ana Maria Belluzzo (1988) e Yvoty Macambira (1985), possibilitam inúmeras abordagens da trajetória profissional do pintor. Os desenhos dos projetos originais, confeccionados para ajudar o cliente a decidir por este ou aquele padrão de friso, uma ou outra tonalidade para o fundo de uma ornamentação para o teto, permitem conhecer o processo de criação de uma arte praticamente desaparecida das residências (FIGURA 20).

Este projeto de pesquisa percorre o caminho inverso dos projetos acima descritos. Nos dois primeiros casos trata-se da exploração de uma coleção do acervo, caracterizando um processo no qual a pesquisa qualifica a coleção adquirida ou doada e promove a sua difusão latravés do tratamento
13. Proponentes: Solange Ferraz de Lima e Vânia Carneiro de Carvalho, curadoras do Serviço de Documentação Textual e Iconografia e Denise Peixoto, Educadora e Supervisora do Serviço de Atividades Educativas.

14. A coleção Oreste Sercelli réune documentos de natureza variada, produzida entre $186 \mathrm{e}$ 1925. O núcleo principal são as 130 pranchas de desenhos e projetos originais (aquarela sobre cartão), além de dois cadernos de campo. Acompanham o núcleo principal cartões postais (utilizados como modelos decorativos), cartas de clientes, certificados profissionais, retratos fotográficos de Oreste Sercelli, da equipe de trabalho em São e fotografias documentando obras realizadas; objetos de trabalho tais como frascos com tintas confeccionadas artesanalmente, pincéis, suporte em couro para pincel,folhas para douração; e sua biblioteca, com 36 títulos entre revistas de decoração e atualidades, repertórios de modelos alemães, italianos e franceses, e tratados arquitetônicos. 


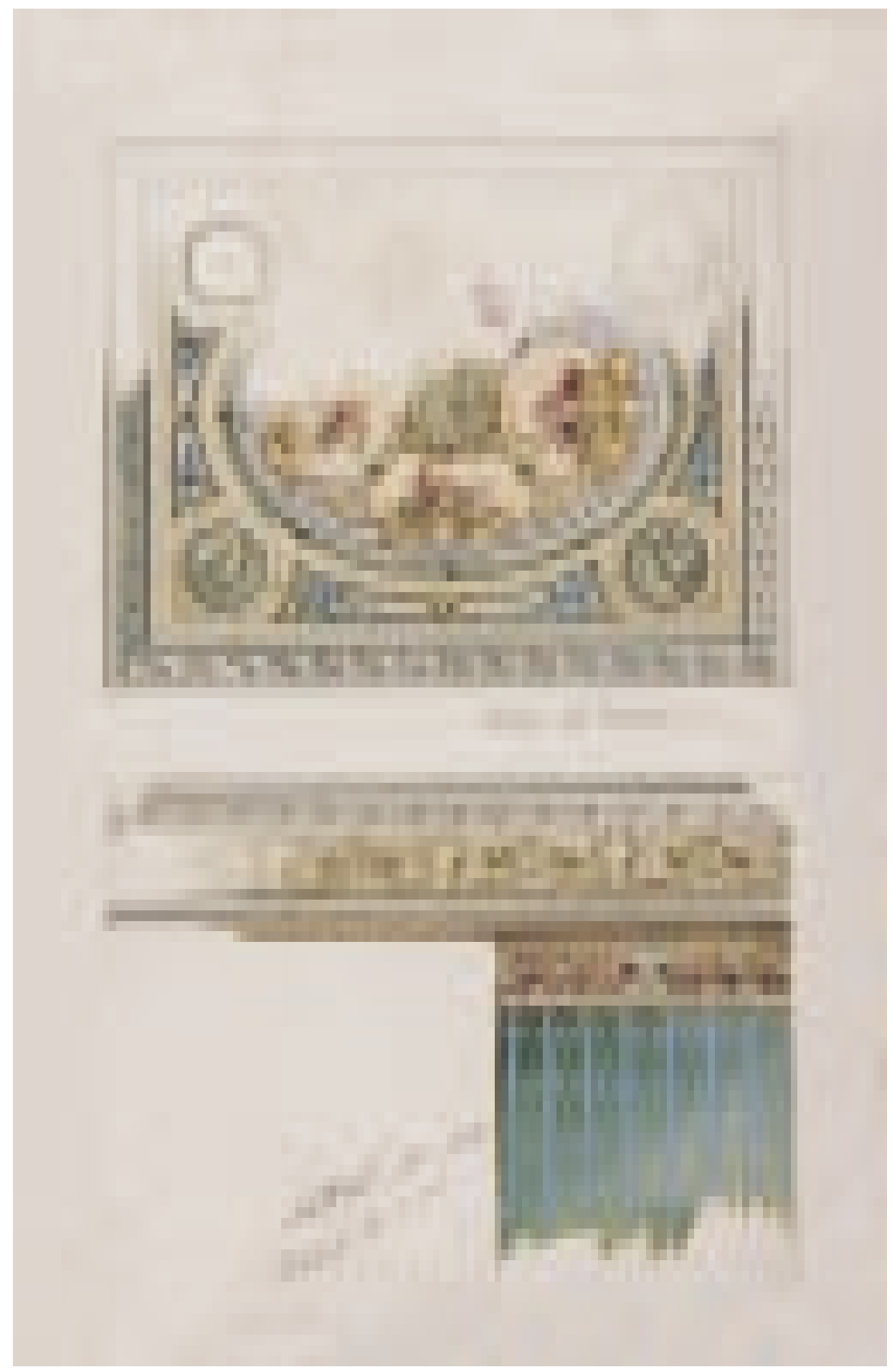

FIGURA 20 - Sala de visita. Oreste Sercelli e Filho. S. Paulo. 12-8-27. Prancha com desenho original em aquarela e grafite, 1927. Coleção Sercelli. Acervo Museu Paulista da USP. 
documental expresso através do banco de dados) bem como a difusão do conhecimento gerado a partir de seu estudo/desde as formas mais tradicionalmente conhecidas do meio acadêmico - artigos, apresentações em eventos etc., aulas e palestras - até exposições e demais produtos culturais). Neste caso, trata-se de desdobramento de parte da pesquisa desenvolvida no âmbito da tese de doutorado, pois a coleção foi localizada durante o período de levantamento de fontes para este trabalho. Ela encontrava-se em posse de suas netas, as irmãs Bruna e Florença Sercelli e foi adquirida pelo Museu Paulista em julho de 2001. Dessa maneira, as atividades de pesquisa acadêmica reverteram em ampliação do acervo em um dos campos definidos de atuação do Museu - o Universo do Trabalho, cumprindo uma trajetória igualmente desejada naquela concepção de curadoria que tratamos - a dupla mão entre a pesquisa e as obrigações para com o acervo, implicadas, neste caso, na política de ampliação de coleções correlatas ao perfil institucional. A pesquisa está direcionada, em um primeiro momento, para a alimentação do banco de dados e um desdobramento mais aprofundado de documentação da obra de Oreste Sercelli, implicando a futura produção de um catálogo. Também está prevista a configuração de um instrumental para análises formais que mobilize um vocabulário controlado derivado do confronto entre os modelos disponiveis e as escolhas de uso e reciclagem por parte do artesão e mesmo de seus clientes. $O$ desenvolvimento do projeto envolverá pesquisadores de outras áreas, como a restauração de pintura mural, da arquitetura e artes plásticas e aplicadas.

O projeto Gênero e artefato: sentidos e performance social no espaço doméstico focaliza, na perspectiva da cultura material, a constituição sociocultural das categorias masculino e feminino através da ação corporal envolvendo objetos da casa. O objetivo, entre outros, é apontar a indissociabilidade entre a dimensão performática da vida social e a produção de sentidos de gênero na sociedade moderna, especialmente a paulistana entre 1870-1920. O projeto resultou da tese de doutorado Gênero e artefato: o sistema doméstico na perspectiva da cultura material. São Paulo, 1870-1920 (CARVALHO, 200 1). Sentidos, valores e práticas de diferenciação entre homens e mulheres na moradia abastada paulistana entre os anos de 1870 e 1920 foram tratados através de ampla documentação - romances, literatura de viagem, revistas, manuais, fotografia e objetos, entre os quais boa parte encontra-se no Museu Paulista. Nesse novo patamar de análise, - objetivo era trabalhar problemáticas materiais e visuais que reunissem tipologias diversas de fontes documentais. Foi possível demonstrar como a formação de identidades sexuadas diferentes e complementares tem como eixo constitutivo a experiência visual do espaço da casa. A decoração doméstica sintetiza visualmente noções de conforto, beleza, modernidade, bem-estar e tradição. Este estudo, por sua vez, trouxe novos insumos para a reflexão sobre o retrato, articulando-se ao projeto Cultura Visual: entre arte e história acima apresentado.

Por fim, a História do próprio Museu Paulista, instituição centenária, e da construção de seu edifício, encontra-se também registrada fotograficamente. Um conjunto de negativos de vidro documenta as atividades no Museu Paulista e seu acervo desde a década de 1920. Na coleção Tommaso Gaudenzio Bezzi - arquiteto italiano responsável pelo projeto do edifício que abriga o museu -encontramos preciosos registros externos e internos da construção ocorrida entre 1885-1890 (83 ampliações em albumina). A 
15. Curadoria geral de Heloisa Barbuy. produção fotográfica relativa à trajetória do Museu reúne aproximadamente 3.600 negativos de vidro e de acetato, além das cópias em papel. Parte dessas coleções foi mobilizada para a pesquisa e elaboração de duas exposições referentes ao edifício Monumento do Ipiranga - a primeira, temporária, marcou a comemoração do centenário do edifício (1990) e gerou o catálogo Às margens do lpiranga (MENESES, 1990). O projeto mobilizou não só a equipe do SVDHICO, mas também as equipes do Serviço de Objetos. A segunda exposição, de longa duração, inaugurou a a la expositiva dedicada ao Universo do Trabalho' ${ }^{15}$. A maquete em gesso confeccionada por Bezzi constitui o eixo central em torno do qual são recuperados aspectos da trajetória da construção do edifício e da instalação do Museu nele. Finalmente, os registros fotográficos que informam sobre a trajetória do Museu Paulista e de seu edifício foram mobilizados pelos pesquisadores da instituição para a elaboração do livro Museu Paulista. Um monumento no Ipiranga. História de um edifício centenário e de sua recuperação (WITTER; BARBUY, 1997).

A coleção Santos Dumont é um bom exemplo de acervo que une tipologias textuais, tridimensionais e iconográficas - com 323 imagens originais que registram as experiências aeronáuticas do inventor. A coleção contempla ainda manuscritos, papelaria de escritório, biblioteca e objetos, num total de 1.400 itens. O Museu, pela sua natureza heterogênea, é uma instituição privilegiada para a guarda de coleções complexas como esta, reunindo além de documentos pessoais e de trabalho do inventor, aqueles de cunho comemorativo e jornalístico (BARBUY, 2000 ; LIMA, 2000, p. 38-40) (FIGURA 21 ).

Pesquisas e pesquisadores

Acompanhando o aumento de suas coleções e a produção de instrumentos de pesquisa, desde 1990 o SVDHICO vem aprimorando suas atividades de prestação de serviço à comunidade através do desenvolvimento de atendimentos de caráter técnico-científico, visando a orientar e instrumentalizar instituições que de alguma forma atuam na gestão de documentos. (FIGURAS 22, 23).

Não se pode contar ainda com um levantamento sistemático dos trabalhos que se alimentaram das coleções e fundos de arquivo que constituem o SVDHICO. É notório, não obstante, que pesquisadores de primeira linha como Affonso de Taunay, José Honório Rodrigues, Emília Viotti da Costa, Warren Dean e Sérgio Buarque de Holanda, há tempos já utilizavam os acervos do Museu na fundamentação de seus trabalhos, como atestam os trabalho de Levi (1977), Hutter (1972), Makino (1977/78) e Neme (1974). Além dos instrumentos de pesquisa já citados, o acervo do SVDHICO foi objeto de várias descrições a apresentações ICOMISSÃO PATRIMÔNIO CULTURAL, 2003, p. $116-129 ;$ DOCUMENTOS, 1976, p. 225-238; FERNANDES, 1998, p. 243-259; MAKINO, 1977/78, p. 207-21 1; MALHEIRO, 1977/78, p. 201-205; TAUNAY, 1937; WITTER; BARBUY; LIMA, 1999, p. 76-1111.

Vale a pena percorrermos alguns dados que apontam para a especialização e o crescimento do interesse dos acervos iconográficos e textuais para os grupos de pesquisa. Entre 1990 e 1994, o SVDHICO atendia entre 100 e 150 consultas anuais. Entre 1995 e 1998, as consultas mantiveram-se entre 200 


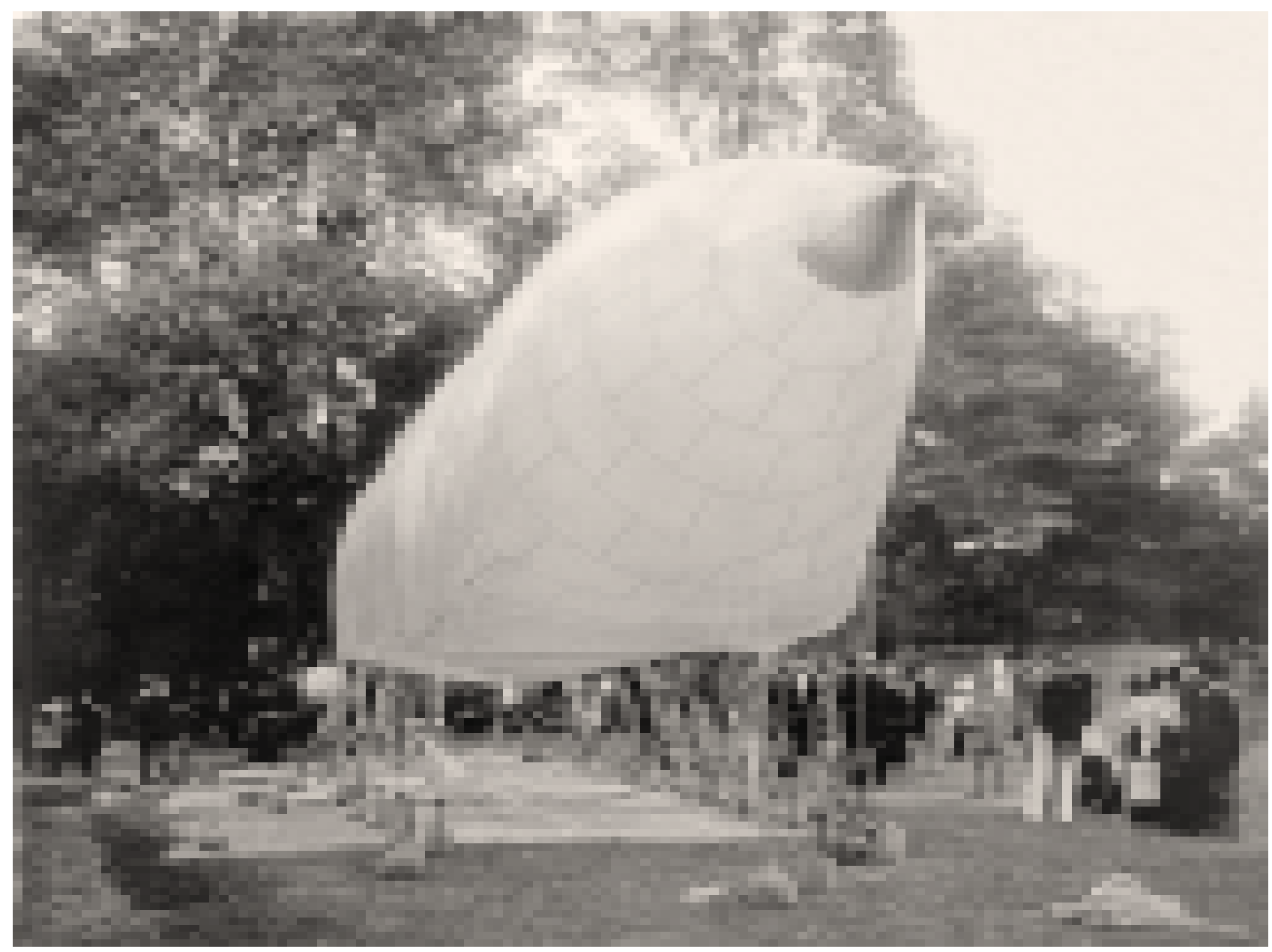

FIGURA 21 - Dirigível n. 2, s.d., fotografia p\&b, gelatina, 16,6 22,9 cm. Coleção Santos Dumont. Acervo Museu Paulista da USP. Reprodução de Hélio Nobre. 
Crescimento do acervo iconográfico

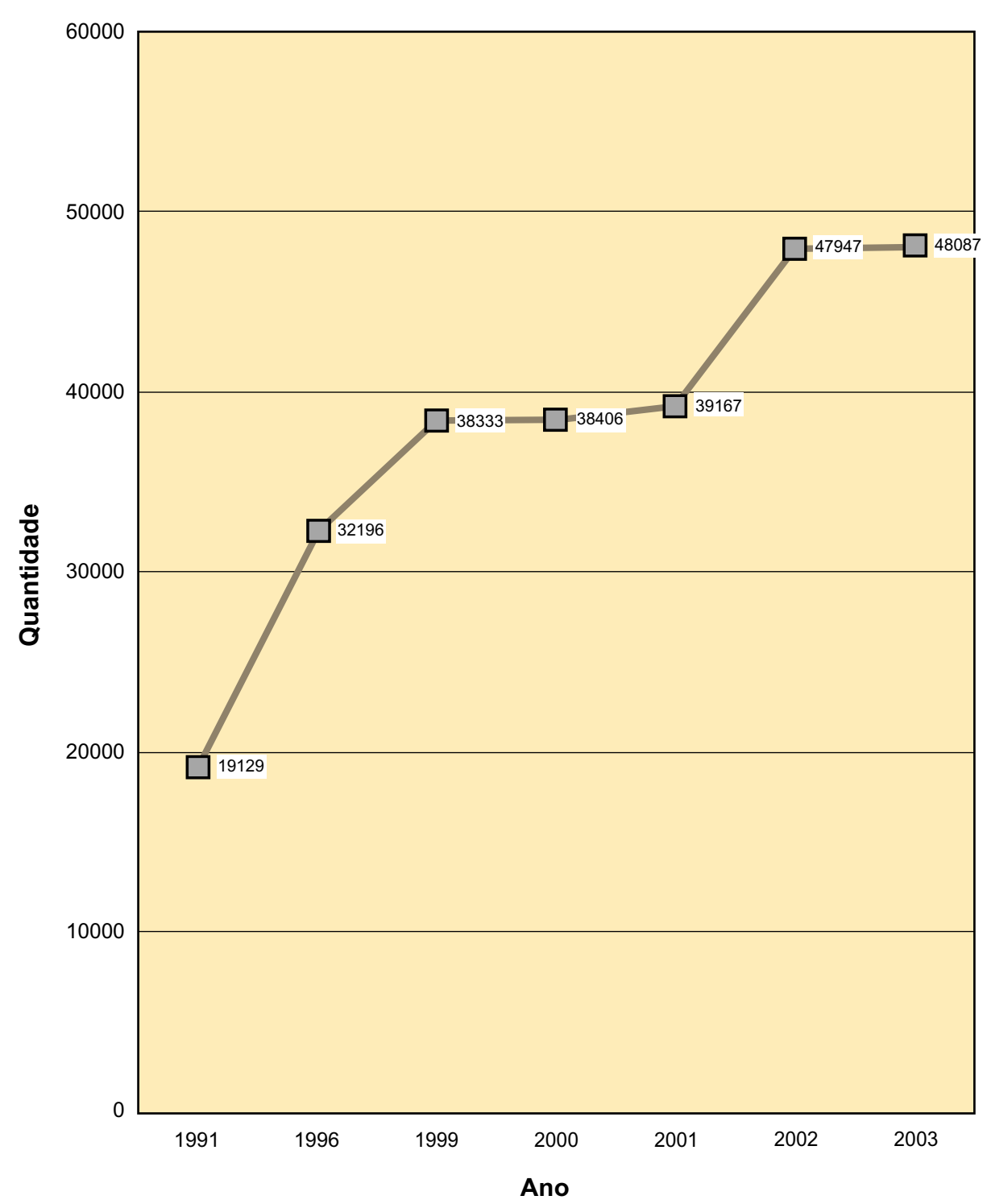

FIGURA 22 - Gráfico de crescimento do acervo iconográfico 


\section{Crescimento do acervo textual}

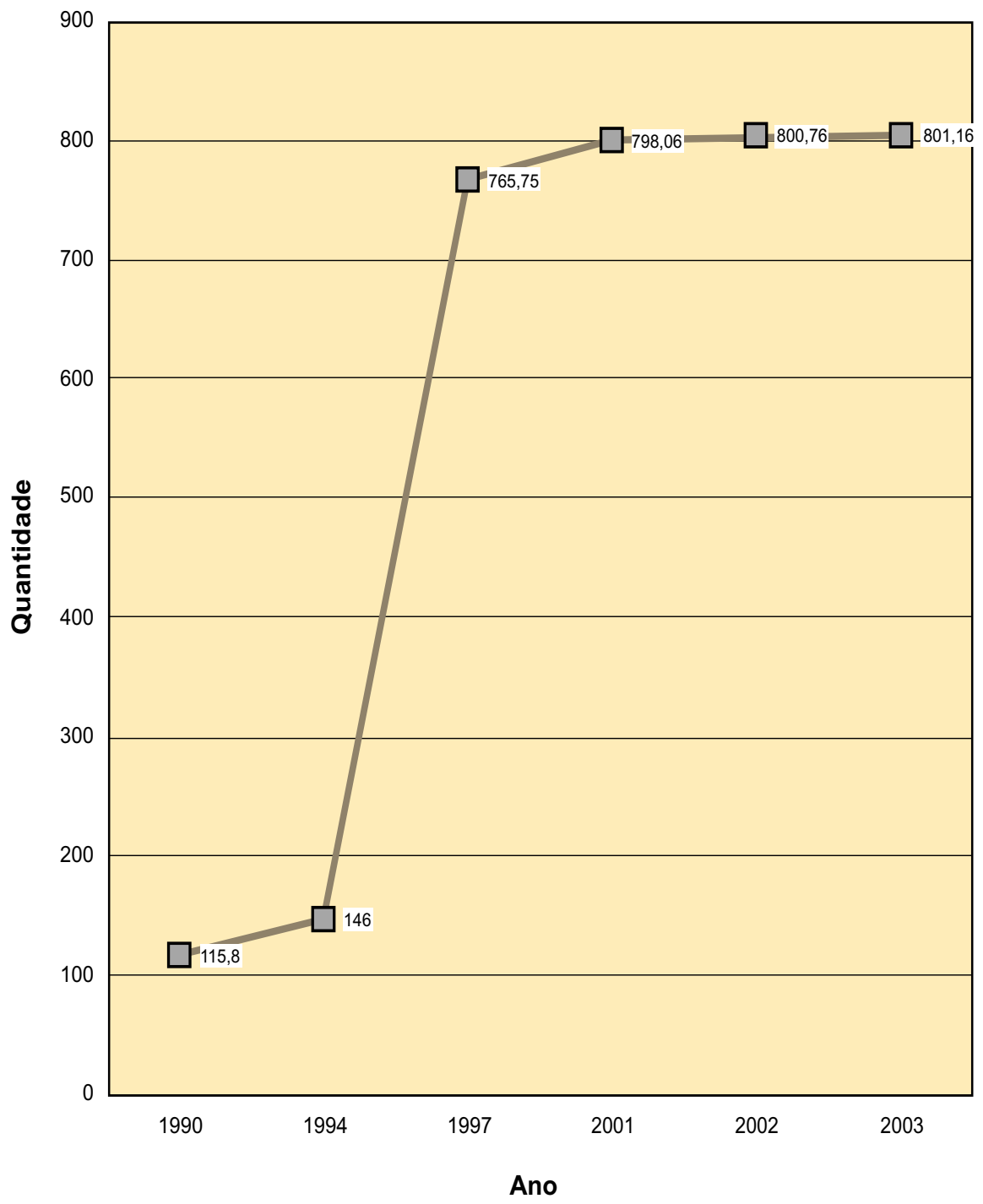

FIGURA 23 - Gráfico de crescimento do acervo textual 
16. João Baptista de Campos Aguirra era um advogado que, ao longo de sua vida profissional, acumulou inúmeros documentos e produziu documentação de referência relativa a compras, vendas, heranças e partilhas de terras e terrenos no Estado de São Paulo.A sua coleção foi adquirida pelo Museu Paulista em 1961 e compunha-se basicamente de fichas referenciando a localização de inventários e escrituras, mapas e plantas, além de recortes de jornais e fotografias. e 300 por ano. Em 1997 foram 246 consultas, sendo 70\% ao acervo textual. Já em 1998 realizaram-se 278 consultas, 60\% aos acervos textuais. $\bigcirc$ crescimento das consultas veio acompanhado de uma maior procura por documentos iconográficos, tanto para o uso acadêmico e editorial quanto publicitário. $\bigcirc$ Fundo Museu Paulista, recém-organizado, é um dos mais acionados para a pesquisa, fazendo frente à tradicional coleção João Baptista de Campus Aguirra ${ }^{16}$.

Com as comemorações dos 500 anos do Brasil, entre 1999 e 2000 ocorreu um salto na quantidade de consultas atendidas e uma inversão nas fontes documentais mais procuradas. Foram 773 atendimentos, com destaque para as pesquisas aos acervos iconográficos, principalmente a coleção Militão Augusto de Azevedo, e as coleções de cartões postais e imagens da cidade de São Paulo (originais fotográficos, desenhos, gravuras e impressos).

A curva ascendente continua entre os anos de 2001 e 2002 com 779 consultas. O foco permanece na coleção Militão e na coleção de jornais d'O Estado de S. Paulo, provavelmente pela conjunção do ineditismo e/ ou da facilidade de acesso que o Museu proporcionou a estes dois conjuntos documentais. Até outubro de 2003, o SVDHICO atendeu 201 consultas. Cinco anos mais tarde, observa-se a inversão da situação de 1998: hoje, as coleções iconográficas são as mais requisitadas, perfazendo o total de $60 \%$ das consultas.

A definição do Museu como unidade universitária especializada teve como resposta o afluxo de consulentes cada vez mais dedicados à pesquisa não só àquela voltada para o mercado editorial e expositivo, mas especialmente à que se serve fortemente de nossa matéria-prima para a produção acadêmica. Para exemplificar, observe-se o ano de 2003. O perfil dos consulentes atendidos obedece à seguinte tipologia, em ordem decrescente: mestrandos, doutorandos, graduandos e graduados (contribuição para pesquisas de mestrandos e doutorandos, publicação de livros, exposições, trabalhos de conclusão de cursos, trabalhos de iniciação científica), pesquisadores autônomos (trabalhos publicitários e expositivos), docentes e alunos cursando o ensino médio.

A organização do Arquivo Permanente do Museu Paulista alimentou trabalhos de reflexão sobre o papel do Museu Paulista no cenário científico brasileiro, seja no campo da História da Ciência, seja no campo histórico propriamente. Bons exemplos são as teses de doutorado de Margaret Lopes sobre a gestão do naturalista Hermann von Ihering, da historiadora Ana Cláudia Brefe sobre a gestão Taunay e o seu projeto expositivo para as comemorações do Centenário da Independência; o artigo publicado nos Anais do Museu Paulista sobre as relações de Taunay e os artistas convidados para produzir as pinturas históricas, que ornamentam as paredes do museu, resultado da pesquisa de pósdoutorado da historiadora da arte Cláudia Valladão (2003); a pesquisa da historiadora Maraliz de Castro Vieira Christo sobre o tema Bandeirantes na obra de Henrique Bernardelli; os capítulos de livro sobre Pedro Américo no espaço memorialista da Independência, escritos por Claudia Valladão e Cecília Helena de Salles Oliveira (BREFE, 1999; CHRISTO, 2002; LOPES, 1993; VALLADÃO, 2003; VALLADÃO; OLIVEIRA, 1999); as dissertações de Maria Cristina Costa, Liana Rosemberg e Eduardo Morettin, também focalizando as relações de Taunay com artistas e produtores culturais (COSTA, 1985; MORÉTTIN, 1995; 
ROSEMBERG, 1998). Também os docentes do Museu Paulista e seus orientandos apóiam parte de seus estudos e projetos na documentação textual e iconográfica deste Serviço (ALMEIDA, 1999; BARBUY, 2001; BITTENCOURT, 2003; CARVALHO, 2001; ELIAS, 1996; HÖRNER, 2002, 2003; LIMA, 2002; MAKINO, 1994, 2002, 2003; MILANI, 1998; OLIVEIRA, 1995, 2000, 200 1; OLIVEIRA, 2001 ; PETRELLA, 1999; RIBEIRO, 1997).

atendimento de consultas também proporciona à instituição uma rica troca de experiências. Experiências estas que são traduzidas em fornecimento de instrumentos de pesquisa, elaborados pelos próprios pesquisadores, como: a transcrição do livro-copiador de Cartas de Militão Augusto de Azevedo; análise do Álbum Comparativo da Cidade de São Paulo (1862/1887) e do Álbum Vistas de São Paulo; transcrição do Diário de Viagens de Militão Augusto de Azevedo, e da relação de correspondências selecionadas no Arquivo Permanente do Museu Paulista e coleção Affonso d'Escragnolle Taunay, cedidos por Íris Morais Araújo, e o último, por Karine Anhezini de Araújo.

Um levantamento ${ }^{17}$ nos cadastros de consulentes do SVDHICO, entre os anos de 2001 e 2003 demonstra de forma clara a tendência de uso de seu acervo para a produção de conhecimento:

- 46 doutorados, mestrados e monografias de especialização em fase de desenvolvimento ou concluídos nesse período que de alguma forma acionaram o acervo do SVDHICO - Aureli Alves de Alcântara. Taunay e a iconografia cafeeira: discurso e recurso (monografia, CEMAU/USP); Ana Cristina Alves Balbino, 0 Cotidiano Através dos Trilhos, Trabalhos e Práticas da SPR (1870/1890) (mestrado, PUC/SP); Ana Maria de Alencar Alves, Um Museu de Ciências Naturais na História de São Paulo: $O$ museu do lpiranga (mestrado, FFLCH/USP); Camila Lacerda Soraia, A Educação e o OESP (1961 / 1965) (mestrado, USP); Caleb Faria Alves, Benedito Calixto e a construção do Imaginário Republicano (doutorado, FFLCH/ USP); Carla Jacques Ibrahim, Retratos e Revelações de uma Fotógrafa Centenária (mestrado, Unicamp); Carlos Blaya Perez, O Perfil dos Usuários de Arquivo Fotográficos (doutorado, Universidade Federal de Santa Maria); Christianne Silva Vasconcellos, A Representação Fotográfica da Escravidão (mestrado, Unicamp); Clarete Paranhos da Silva, Geociência no Brasil do Século XVIII ldoutorado, Unicamp); Cláudia Panizzolo, O Império dos Bacharéis: um Estudo sobre a Imprensa Periódica Paulistana no Século XIX (doutorado, PUC/SP); Claudia Polastre, São Paulo Musical (1765/ 1822) (doutorado, USP); Danilo José Zioni Ferretti, A Invenção da Paulistanidade: Identidade, Historiografia e Política (doutorado, FFLCH/USP); Dimas de Fonte Silva, A Ciência em Santos Dumont (mestrado, UERJ); Fraya Frense, Sociabilidade de Rua em São Paulo na Virada do Século XX (doutorado, FFLCH) USP); Gavin Adams, A Mirada Estereoscópica e sua Expressão no Brasil (doutorado, ECA/USP); Gilberto Habib Oliveira, O Espólio Bernardelli no Museu Paulista e o pensamento Museológico de Affonso de Escragnolle Taunay (CEMAE/USP); Íris M. Araújo, Sobre uma Categoria Narrativa: "Progresso" (mestrado, FFLCH/USP); Janes Jorge, O Tietê e outras Águas em São Paulo (doutorado, FFLCH/USP); José Costa Oliveira Filho, O edifício do Museu Paulista:um pouco da história do edifício - Monumento de Bezzi (mestrado, FFLCH/USP); Karin Reimer, Mulheres Brasileiras: Mitos e Metáforas (mestrado, Faculdade de Moda Santa Marcelina); Luiz Humberto
17. Este levantamento contém dados parciais. Os títulos das pesquisas aqui relacionadas são muitas vezes imprecisos ou provisórios.Os projetos estão sob o nome do pesquisador que preencheu o cadastro do SVDHICO, que não é necessariamente o organizador ou autor principal da obra). 
Martins Flantes, Teatro de Jorge Andrade: Dilemas entre Memória, História e Ficção (1951/1969) (doutorado, PUC/SP); Magda Barros Biavaschi, O Crescimento do Direito de Terra no Brasil (doutorado, UNICAMP); Marcelo Eduardo Leite, Cartes-de-Visite Brasileiras (doutorado, UNICAMP); Marcelo Mari, Mário Pedrosa e o Estadão (doutorado, FFLCH/USP); Marcelo Santos de Abreu, Regionalismo e Imaginária Urbana: escultura pública das cidades de Niterói e São Paulo na primeira República (mestrado, UFF); Márcia Maria Cabreira, A Imigração Síria e Libanesa em São Paulo (doutorado, FFLCH/USP); Márcio Roberto Alves dos Santos, Tribos Indígenas e Bandeirantes Paulistas no Sertão do Rio São Francisco (mestrado, UFMG); Maria de Fátima de Mello Berreto Campello, A Construção da Visualidade da Cidade de Maceió (doutorado); Maria do Carmo Couto, A Formação Italiana de Rodolpho Bernardelli (mestrado, IFCH/UNICAMP); Maurício Guindani Romanini, A Trajetória de Prudente até 1894 sob a Óptica da Propaganda na Imprensa (mestrado, UMESP); Maurício Nunes Lôbo, Imagens da Urbanização e Cartões Postais de Santos (1900/1920) (mestrado, UNICAMP); Maurício Sérgio Dias, Projeto Caminhos e Fronteiras: Gestão Sérgio Buarque de Holanda no Museu Paulista (mestrado, UNESP); Moisés Poletini, As Obras Sacras de Benedito Calixto (mestrado, UNICAMP); Mônica Muniz Pinto de Carvalho, Fronteiras Subjetivas da Cidade: $\bigcirc$ Distrito de Anhanguera (doutorado, PUC/SP); Nelson Antonio Alesi, São Paulo, Café e Industria: de Vila a Metrópole (doutorado); Nilva Costa da Luz, A Presença da Cia. Genêsio Arruda no Teatro Regionalista de São Paulo (mestrado/UNESP); Oséas Singh Júnior, Almeida Júnior: o Tema Histórico (mestrado, UNICAMP); Orlando Franco Maneschy, Olhar Desdobrado: perspectiva sobre Fidanza (doutorado, PUC/SP); Patrícia Ferreira de Souza Lima, Correspondências da Imperatriz Leopoldina (doutorado,UFRJ); Renata Alves da Silva, Esculturas nos Espaços Públicos e Privados (mestrado); Renato P. Dória, Entre o Belo e o Útil: Ensino do Desenho no Brasil do Século XIX (doutorado, FAU/USP); Rodolfo Jacab Hessel, Porto Feliz: a Iconografia Monçoeira e Sérgio Buarque de Holanda (mestrado, UNESP); Sérgio Pereira Antunes, A administração de Washington Luís (doutorado, FFLCH/USP); Silvia Ahlers, Coronéis, Capitães e Escravos em Pilar (mestrado, FFLCH/USP); Silvia Queiroz Ferreira Barreto Lins, Para Além dos Trilhos e das Tropas (doutorado, FFLCH/USP); Simone T. Keith, Santos Dumont (mestrado, NC State University); Telma Campanha de Carvalho, Fotografia de Imprensa (doutorado, ECA/USP); Vera Lúcia Nagib Bittencourt, A Regência de D. Pedro: um Estudo sobre as Circunstâncias Históricas e a Cultura Política no Brasil ( 1820 / 1822) (mestrado, FFLCH/USP); Walter Pires, Parcelamento de Terras: Cambuci, Aclimação e Vila Mariana (mestrado, FAU/USP).

- 19 trabalhos de conclusão de curso e projetos de iniciação científica: Andréa da Silva Cruz, Vistas da Cidade de São Paulo: São Paulo Óntem, Hoje e Sempre (Faculdade SENAC de Comunicações e Artes); Cleusa Duarte Alves, História Cultural da Fotografia (Universidade do Grande ABC); Erik Horner, Revolução Liberal de 1842: Protagonistas e Movimentações Militares (FFLCH/ USP); Íris Morais Araújo, Fotografando seu Tempo (FFLCH/USP); Liliane Aparecida Oliveira, Imaginário da Independência: Fundo Prefeitura Municipal de lguape (FFLCH/USP); Maira Dal Corso Ribeiro, Fotos Antigas do Ipiranga (antropologia, Universidade São Marcos); Mariana Brambilla Bortoloto, Sítio Ressaca: Jabaguara 
(UMESP); Marina Castilho Takami, Estudo Comparativo de Retratos: Retratos de Estúdio (1 875/1885) (UNESP); Natalia Falco de Albuquerque, O Comércio de São Paulo (UMESP); Paloma Alves de Oliveira, Vida e Obra de Santos Dumont (USP); Paulo Assis Barbosa, Santa Casa de São Paulo: Técnicas Construtivas (FAU/ USP); Polyana Canhête Lopes, A Bienal sem o MAM (UNESP); Rafaela de Andrade Deiab, São Paulo pela Lente de Militão: vendo Retratos (FFLCH/USP); Raquel de Sales Lima Magalhães, Análise Arquitetônica do Ecletismo no Brasil (Universidade Anhembi Morumbi); Renata de Souza Neves Salinas, Santa Casa de São Paulo: Evolução do Edifício do Hospital Central (FAU/USP); Roberto de Gouveia e Freitas Júnior, Projeto de Restauro do Quadrilátero do Tatuapé (FAU/USP); Tatiana Pontes, História da Fotografia: Retratos de Militão (Faculdade SENAC); Vanessa dos Santos Bodstein Bivor, Os Estrangeiros na Província de São Paulo: uma análise a partir do discurso testemunhal (1827/1878) (FFLCH/USP).

- 24 produtos editoriais (livros, revistas e vídeos): Amanda Carvalho, Os Sertões: 100 Anos (vídeo, TV USP); Antonio Venancio Filho, Raízes do Brasil: uma cinebiografia de Sérgio Buarque de Holanda (vídeo, Vídeo Filmes); Bruna de Grande Falci, Catedral da Sé: a engenharia como obra de arte (livro, Formarte); Carla Aparecida dos Santos, Monumento do Ipiranga (artigo, Revista Histórica); Carlos Eugênio Marcondes de Moura, Doce como Açúcar (livro); Eloá Ramos Chouzal, Gessy Lever: História e Histórias de Intimidade com o Consumidor Brasileiro (livro, Grifo); Francisca Arieira Couto, Uma Breve História das Capitais Brasileiras (programa TV, Giros Produções); Ilka Stern Cohen, As Revoluções na Cidade: São Paulo 1924/1932 (artigo); João Alexandre Viégas, Santos Dumont: a invenção do futuro (livro e site); Leandro da Silva Araújo, Iconografia do Pico do Jaraguá (livro); Lorelai B. Kury, Representações da Natureza em Hércules Florence (livro, Fundação Oswaldo Cruz); Lucíola M. Silveira de Morais, Princesa Isabel (livro, Duna Dueto); Maria Solange Santos, Expresso Brasil: Madeira-Mamoré (documentário); Marilda Nagamini, História da Ciência e Tecnologia no Brasil (livro); Marcelo Aith, 70 Anos da Revolução de 1932 (documentário, TV Cultura); Marjorie C. F. Medeiros, Santos no Tempo de Militão (livro); Maurício Cardoso, Empreendedores Paulistas (livro, FFLCH); Orna Messer Lenin, Poesias de Fagundes Varela (livro, UNICAMP); Paulo Fernando Prado Levy, Santos Dumont (livro, Foglia Comércio e Editora Ltda); Ricardo Mendes, Noticiário Geral da Photographia Paulistana (livro, Centro Cultural São Paulo); Sérgio Brusco, Calendário (Escola 7, Editora Gráfica Ltda); Stédio Flávio Maloney, História de Rondônia e Ferrovia Madeira-Mamoré (livro e site, Dinamarca); Susana Margarida Munch Miranda, Comemorações dos Descobrimentos Portugueses (Publicação Comissão Nacional); Urquizia Maria Borges, Relações familiares da Família Fernando Pacheco Chaves (livro, UNESP) e Valéria Borges Pereira Cegal, Tempo e Memória Comercial (livro institucional).

Projeções, encaminhamentos

SVDHICO tem se preocupado em integrar-se a grupos nacionais e internacionais que estão envolvidos com estudos de cultura material e cultura visual. 
18. Coordenadores: Fernando Aguayo, Lourdes Roca (Intituo Mora), Solange Ferraz de Lima e Vânia Carneiro de Carvalho (Museu Paulsita).
É nessa perspectiva que se fomenta o desenvolvimento de pós-doutorados, com base em projetos envolvendo o acervo iconográfico. Este é o primeiro ano em que o SVDHICO recebe um pós-doutorando. Trata-se da Profa. Dra. Ana Maria Mauad, docente do Departamento de História da Universidade Federal Fluminense e integrante do Laboratório de História Oral e Imagem da UFF, que desenvolve pesquisa voltada para a formação de vocabulários controlados relativos aos atributos formais de retratos do século XX.

Nesse mesmo sentido estabeleceu-se, em 2003, o Convênio Internacional entre o Instituto de Investigaciones Dr. José Maria Luis Mora (IM, DF/México) e o Museu Paulista da USP18. O trabalho com o Laboratório Audiovisual de Investigación Social do Instituto Mora visa à realização conjunta de seminários e intercâmbio de docentes. O resultado esperado da cooperação é a difusão e consolidação de conhecimentos teórico-metodológicos na análise de documentação visual relacionada ao espaço urbano. Trata-se de fomentar seminários de pesquisa, que articulem quatro áreas - História Visual, História Urbana, Ciência da Informação e Antropologia Visual - que hoje se destacam na pesquisa sobre fontes documentais fotográficas. O ciclo de seminários foi apresentado no México em 2003 e deverá ocorrer em São Paulo em 2004. Na mesma trilha está a recente colaboração com o Grupo de Pesquisa em Cultura Visual, Mídia e História, coordenado pelas Profas. Dras. Cristina Meneguello e lara Lis Franco Schiavinatto Carvalho Souza (Depto. História IFCH - Universidade Estadual de Campinas).

Nesta perspectiva, o SVDHICO vem definindo-se como centro de referência para o desenvolvimento da cultura e do saber histórico bem como para a difusão de formas de tratamento físico e documental. O SVDHICO cumpre assim funções plenamente sintonizadas com aquelas previstas para 0 raio de ação de um museu histórico, sempre disponibilizando elementos que permitam o questionamento do passado nas novas interpretações do presente .

\section{REFERÊNCIAS}

ADAMS, Gavin; CARVALHO, Vânia Carneiro de; LIMA, Solange Ferraz de. Poses do 19 (19th Poses). São Paulo: Museu Paulista e Espaço Digital, 2002.Vídeo. Grand Prix Ciném’Art du Court Métrage/ Avicom-ICOM, 2002.

ALMEIDA, Adilson José. Uniformes da Guarda Nacional, 1831-1852; a indumentária militar na organização e funcionamento de uma associação armada. 1999. 251 p. Dissertação (Mestrado) Faculdade de Filosofia, Letras e Ciências Humanas, Universidade de São Paulo, São Paulo, 1999.

ALSFORD, Stephen; GRANGER, Frederick. Image automation in museums. The Canadian Museum of Civilization's Optical Disc Project. International Journal of Museum Management and Curatorship, v. 6, p. 187-200,1987.

BARBUY,Heloisa.A Cidade-Exposição: comércio e cosmopolitismo em São Paulo, 1860-1914.2001.169 p. Tese (Doutorado) - Faculdade de Arquitetura e Urbanismo, Universidade de São Paulo, São Paulo, 2001. 
BEARMAN,D. Collection Software: a new challenge for archives and museums. Archival Informatics Technical Report, v. 1, n. 2, Summer 1987.

BELLUZZO, Ana Maria.Artesanato, arte e indústria. 1988.523 p.Tese (Doutorado) - Faculdade de Arquitetura e Urbanismo, Universidade de São Paulo, São Paulo, 1988.

BESSER, Howard. Digital images for museums. Museum Studies Journal, v. 3, n. 1, p. 73-81, 1987.

BITTENCOURT, Vera. A regência de D. Pedro (1821/1822): aspectos da atuação de José Bonifácio no ministério. Início: agosto/2002. (Coleções José Bonifácio/Marquês de Valença). Mestrado em História Social/ Dep. de História da USP sob a orientação de Cecília Helena de Salles Oliveira.

BREFE, Ana Claudia Fonseca. Um lugar de memória para a nação. O Museu Paulista reinventado por Affonso d'Escragnolle Taunay. 1999.304 f.Tese (Doutorado) - Instituto de Filosofia e Ciências Humanas, Universidade Estadual de Campinas, Campinas, 1999.

BRILLIANT, Richard Brilliant. Portraiture. London: Reaktion Books, 1991.

BURKE, Peter. Eyewitnessing.The uses of images as historical evidence. London: Reaktion Books, 2001.

CACALY, S. Image et videodisque. Paris: LDF, 1989.

CARVALHO, Vânia Carneiro de. Banco de Imagens: do consumo ao aprendizado. In: ENCONTRO DO CENTRO DE DOCUMENTAÇÃO E APOIO À PESQUISA-CEDAP, 2., 2000, Assis. Programa $e$ Resumos... Assis: UNESP/Assis, 2000. p. 24-25.

Gênero e artefato: o espaço doméstico na perspectiva da cultura material. São Paulo,18701920.2001.309 p.Tese (Doutorado) - Faculdade de Filosofia, Letras e Ciências Humanas, São Paulo, 2001.

. Representações do trabalho. Fotografias: a máquina e o homem, uma história de conquistas? In: ABREU, Adilson Avanci. (Org.). Quantos anos faz o Brasil? São Paulo: [s.n.], 2000. p. 46-48. (Uspiana Brasil 500 Anos).

CARVALHO, Vânia Carneiro de; LIMA, Solange Ferraz de. Os atributos formais da imagem na constituição de sistemas documentais produtivos para a pesquisa.In:SEMINÁRIO SOBRE MUSEUSCASAS: PESQUISA E DOCUMENTAÇÃO, 4., 2002, Rio de Janeiro.Anais... Rio de Janeiro: Casa de Rui Barbosa, 2002. p. 173-180.

.A cidade musealizada: funções e estratégias visuais nas encomendas pictóricas do Museu Paulista em 1922. In: CONGRESSO INTERNACIONAL DE HISTÓRIA DA ARTE, 5., 1993. São Paulo. Atas... São Paulo: Comitê Brasileiro de História da Arte-ECA/USP, 1993. p.169-174.

1997.

.Fotografia e cidade: da razão urbana à lógica do consumo. Campinas: Mercado de Letras, 
. Fotografia no Museu:o projeto de curadoria da Coleção Militão Augusto de Azevedo.Anais do Museu Paulista Revista de História e Cultura Material, Nova Série, São Paulo, v. 5, p. 205-245, 1997.

Fotografias como objeto de coleção e de conhecimento: por uma relação solidária entre pesquisa e sistema documental.Anais do Museu Histórico Nacional, Rio de Janeiro, v. 32, p.15-32, 2000. Edição Alusiva aos 60 anos de lançamento do volume I - 1940 .

Individuo, género y ornamento en los retratos fotográficos, 1870-1920. In: CONGRESO INTERNACIONAL SOBRE IMÁGENES E INVESTIGACIÓN SOCIAL, 1., 2002, México.Anais... México: Instituto de Investigaciones Dr. José Ma. Luis Mora. (ms).

São Paulo Antigo, uma encomenda da modernidade.As fotografias de Militão nas pinturas do Museu Paulista. Anais do Museu Paulista Revista de História e Cultura Material, Nova Série, São Paulo, v. 1, n. 1, p. 147-174, 1994.

CARVALHO, Vânia Carneiro de; LIMA, Solange Ferraz de (Org.). Trilbos e sonbos. Fotografias da Ferrovia Madeira-Mamoré. São Paulo: BNDES/Museu Paulista da USP, 2000. 60 p.

Werner Haberkorn. Suplemento Especial do Diário Oficial do Estado de São Paulo, São Paulo, v. 112, p. 1-4, jan. 2002.

CARVALHO,Vânia Carneiro de;MAKINO, Miyoko (Coord.); LIMA, Solange Ferraz de;BARBUY,Heloisa; ALMEIDA,Adilson de; OLIVEIRA, Cecília Helena de Salles; WITTER, José Sebastião. Museu Paulista: acervos encobertos - o universo do trabalho. In:ABREU,Adilson Avanci. (Org.). Quantos anos faz o Brasil? São Paulo: [s.n.], 2000. p. 15-69. (Uspiana Brasil 500 Anos).

CHRISTO, Maraliz de Castro Vieira. Bandeirantes na contra-mão da história.Projeto História, v. 24, p. 307-335, jun. 2002.

COMISSÃO de Patrimônio Cultural. Catálogo das coleções especiais e acervos museológicos da USP. São Paulo: CPC/SIBI-USP, 2003.p.116-129.

COSTA, Maria Cristina. O retrato feminino na Pintura Brasileira, 1800-1950. 1985. 268 p. Dissertação (Mestrado) - Faculdade de Filosofia, Letras e Ciências Humanas, Universidade de São Paulo, São Paulo, 1985.

DOCUMENTOS do Museu Paulista.Anais do Museu Paulista, t. 27, p. 225-239, 1976.

FERNANDES, Paula Porta S. (Coord.). Guia dos documentos históricos na cidade de São Paulo, 1554/1954. Documentação Textual. São Paulo: Hucitec/Neps, 1998. p. 243-259.

FRANCASTEL, Pierre. A realidade figurativa. São Paulo: Perspectiva, 1965.

HEIDORN, P. Bryan. Image Retrieval as Linguistic and Nonlinguistic Visual Model Matching. Library Trends, v. 48, n. 2, p. 303-325, 1999. 
HÖRNER, Erik.A Revolução de 1842 em São Paulo. Bolsista FAPESP. Início:agosto/2003. (mestrado em História Social/ Dep. de História da USP sob a orientação de Cecília Helena de Salles Oliveira).

A Revolução de 1842 em São Paulo: circunstâncias políticas, operações militares e protagonistas. (Coleções Monte Alegre/ Rafael Tobias de Aguiar/Eduardo Prado/Família Imperial) Bolsista FAPESP. Período: julho/2001 - dezembro/2002, (iniciação científica sob a orientação de Cecília Helena de Salles Oliveira).

HUTTER, Lucy Maffei. Imigração italiana em São Paulo (1880-1889). Os primeiros contactos do imigrante com o Brasil. São Paulo: Univesidade de São Paulo, Instituto de Estudos Brasileiros, 1972. 170 p.

LEVI, Darrell E. A Família Prado. São Paulo: Cultura 70, 1977.

LIMA, Solange Ferraz de. Ornamento e Cidade - ferro, estuque e pintura mural - 1870-1930. 2001. 136 p.Tese (Doutorado) - Faculdade de Filosofia, Letras e Ciências Sociais, Universidade de São Paulo, São Paulo, 2001.

.Trabalho e universo tecnológico. Coleção Santos Dumont: o cotidiano de trabalho de um inventor. In:ABREU,Adilson Avanci. (Org.). Quantos anos faz o Brasil? São Paulo: 2000. p. 38-40. (Uspiana Brasil 500 Anos).

MACAMBIRA, Yvoty. Os mestres da fachada. São Paulo: Centro Cultural São Paulo, 1985.

MAKINO, M.;ALMEIDA,Adilson José;ALCÂNTARA, Aureli Alves de. Imagens de fazendas cafeeiras. Imagem e produção de conbecimento = Image et production de connaissance. Organização de Cecilia Helena de Salles Oliveira e Heloisa Barbuy; tradução Jean Briant. São Paulo: Museu PaulistaUSP, 2002. p. 42-57.

MAKINO, Miyoko. Biografias dos Pintores e Catalogação das obras citadas. Anais do Museu Paulista Revista de História e Cultura Material, Nova Série, São Paulo, v. 1, n. 1, p. 175-178, 1994.

. A Construção da Identidade Nacional: Affonso d'Escragnolle Taunay e a decoração do Museu Paulista, 1917-1937.2003.252 p.Tese (Doutorado) - Faculdade de Filosofia, Letras e Ciências Sociais, Universidade de São Paulo, São Paulo, 2003.

.A documentação histórica do Museu Paulista.Anais do Museu Paulista, t. 28, p. 207-211, 1977/1978.

MALHEIRO, Maria Cecília Stávale. O arquivo Aguirra do Museu Paulista.Anais do Museu Paulista, t. 28, p. 201-205, 1977/1978.

MENESES, Ulpiano Bezerra de.A fotografia como documento. Robert Capa e o miliciano abatido na Espanha: sugestões para um estudo histórico. Tempo, Rio de Janeiro, n. 14, p. 131-151,jan./jun. 2003.

.Plano Diretor. São Paulo: Museu Paulista da USP, 1990. (ms.).

MENESES, Ulpiano T. Bezerra de (Org.). Às margens do Ipiranga: 1890-1990. São Paulo: Museu Paulista da USP, 1991. 
MILANI, Lara B. A maquete da cidade de São Paulo - fontes, pesquisa documental e pesquisa bibliográfica. (Fundo Museu Paulista), Bolsista PIBIC/CNPq/USP. Período: agosto/1996-julho/1998 (iniciação científica sob a orientação de Cecília Helena de Salles Oliveira e co-orientação de Miyoko Makino).

MORETTIN, Eduardo Victorio. Cinema e História:uma análise do filme “Os Bandeirantes”. 1995. Dissertação (Mestrado) - Escola de Comunicações e Artes, Universidade de São Paulo, São Paulo, 1995.

MUSEU PAULISTA. Plano de Metas. São Paulo: Museu Paulista da USP, 2000. (ms.).

MUSEU PAULISTA. Plano Diretor. São Paulo: Museu Paulista da USP, 1997. (ms.).

NEME, Mario. Apossamento do solo e evolução da propriedade rural na zona de Piracicaba. São Paulo: Fundo de Pesquisas do Museu Paulista da Universidade de São Paulo, 1974. (Série História. Coleção Museu Paulista).

OLIVEIRA, Cecilia Helena de Salles. Museu Paulista: espaço celebrativo e memória da Independência. In: BRESCIANI, Stella; NAXARA, Márcia (Org.). Memória e (res)Sentimentos. Campinas: UNICAMP, 2001. p. 197-222.

O espetáculo do Ipiranga: reflexões preliminares sobre o imaginário da Independência. Anais do Museu Paulista Revista de História e Cultura Material, Nova Série, São Paulo, n. 3, 1995.

O espetáculo do Ypiranga: mediações entre história e memória. 2000. 288 p. Tese (Livredocência) - Museu Paulista, Universidade de São Paulo, São Paulo, 2000.

OLIVEIRA, Cecilia Helena de Salles (Org).Museu Paulista: novas leituras. São Paulo:Museu Paulista da USP, 1995.

OLIVEIRA, Cecília Helena de Salles; BARBUY,Heloisa (Org.).Imagem e produção de conbecimento. CNRS - Centro Nacional de Pesquisas Científicas/França, Museu Paulista da USP. In: ENCONTRO INTERNACIONAL IMAGEM E CIÊNCIA, 18., 2002, São Paulo. Anais... São Paulo: Museu Paulista da USP, 2002. p. 13-29.

OLIVEIRA, Cecilia Helena de Salles;VALLADÃO, Claudia. O brado do Ipiranga. São Paulo: EDUSP, 1999.

OLIVEIRA, Lilian Aparecida de. De Império português a Império do Brasil. Análise bibliográfica e estudo de acervos textuais do Museu Paulista/USP. (Fundo Prefeitura de Iguape), bolsista PIBIC/ CNPq/USP. Período: agosto/2000 - julho/2001, (Iniciação científica sob a orientação de Cecília Helena de Salles Oliveira).

PANOFSKY, Erwin. Significado nas artes visuais. São Paulo: Perspectiva, 1979. (1ª. edição 1939). 
PATRIMOINE PHOTOGRAPHIQUE.Actes du colloque sur le patrimoine photographique Cite des Sciences et de L'Industrie. Paris: LDF, 1987.

PAYSAGE DU VIDEODISQUE Banque d'images en France. Paris: LDF, 1986.

PETRELLA, Yara Lígia Mello Moreira. A linguagem das cores nas paisagens urbanas e marinhas de Benedito Calixto. 1999. 203 p. Dissertação (Mestrado) - Faculdade de Arquitetura e Urbanismo, Universidade de São Paulo, São Paulo, 1999.

POINTON, Marcia. Hanging the head. Portraiture and social formation in Eighteenth Century England. London/New Haven:Yale University Press, 1993.

RIBEIRO, Angela Maria Gianeze. Carimbos particulares nas moedas do Brasil Império: formas alternativas de dinheiro. 1997. 206 p. Dissertação (Mestrado) - Museu de Arqueologia e Etnologia, Universidade de São Paulo, São Paulo, 1997.

ROSEMBERG, Liana Ruth Bergstein. Da imagem retórica: a questão da visualdiade na pintura de Pedro Américo no Brasil Oitocentista. 1998. 311 p. Tese (Doutorado) - Faculdade de Arquitetura e Urbanismo, Universidade de São Paulo, São Paulo, 1998.

RUIZ,Adilson; CARVALHO,Vânia Carneiro de; LIMA, Solange Ferraz de; MAKINO, Miyoko.São Paulo Antiga: uma encomenda da modernidade. São Paulo: Museu Paulista-USP; Escola de Comunicações eArtes-USP, 1993.Vídeo.

SMIT, Johanna W. Novas tecnologias e bancos de imagens. (Mesa Documentação Fotográfica e História).In:ENCONTRO REGIONAL DE HISTÓRIA, 12., 1994, São Paulo.Anais... São Paulo:ANPUH, 1994. p. 139-140.

SOUZA, Jonas Soares de; MAKINO, Miyoko (Org.). Diário de navegação. São Paulo: Editora da Universidade de São Paulo; Imprensa Oficial do Estado de São Paulo, 2000. (Uspiana - Brasil 500 anos).

TAUNAY,Affonso de E. Guia da secção bistórica do Museu Paulista. São Paulo: Imprensa Oficial do Estada, 1937.

TESSITORE, Viviane; CARVALHO, Vânia Carneiro de (Org.). Evolução Institucional do Museu Paulista (1891-1963). São Paulo: Museu Paulista, 1992. 170 f. (ms).

. Guias das coleções do Serviço de Documentação Textual e Iconografia. São Paulo: Museu Paulista, 1998. (ms).

. Projeto de organização dos fundos de arquivo e coleções de documentos pertencentes ao Setor de Documentação do Museu Paulista da USP. São Paulo: Museu Paulista, 1991.31 f.(ms).

TESSITORE, Viviane; CARVALHO, Vânia Carneiro de; ZEQUINI, Anicleide (Org.). Inventário do arquivo permanente do Museu Paulista: Fundo Museu Paulista e Fundo Museu Repubicano Convenção de Itu. São Paulo: Museu Paulista, 1994. 170 f. (ms). 
WITTER, José Sebastião (Coord.); BARBUY, Heloisa; LIMA, Solange Ferraz de (Orgs.). Acervos do Museu Paulista/USP (Museu do Ipiranga). São Paulo: IMESP, 1999. p. 76-111.

WITTER, José Sebastião; BARBUY, Heloisa (Org.). Um monumento no Ipiranga: história de um edifício centenário e sua recuperação. São Paulo: FIESP, 1997.

Artigo apresentado em 11/2003. 
O Serviço de Documentação Textual e Iconografia do Museu Paulista

Miyoko Makino, Shirley Ribeiro da Silva, Solange Ferraz de Lima, Vânia Carneiro de Carvalho

$\bigcirc$ artigo faz um balanço dos trabalhos de curadoria realizados durante a década de 1990 pelo atual Serviço de Documentação Textual e Iconografia do Museu Paulista, responsável pelo Fundo MP/Arquivo Permanente, centenas de coleções e fundos textuais e 50.000 peças de iconografia, grande parte delas reunidas em coleções fotográficas. Mostra como o trabalho de documentação extrapola os limites do SVDHICO para integrar-se com as atividades de conjunto do Museu e com outros grupos de pesquisa. Aponta também para novas metodologias de trabalho com imagens que permitem realizar a curadoria de forma integrada à pesquisa interdisciplinar e à difusão cultural. PALAVRAS-CHAVE: Curadoria. Coleções. Museu Paulista. Fotografia. Banco de Dados.Artes Plásticas. Anais do Museu Paulista. São Paulo. N. Sér. v. 10/11. p.259-304 (2002-2003).

The Department of Textual and Iconographical Documentation of Museu Paulista

Miyoko Makino, Shirley Ribeiro da Silva, Solange Ferraz de Lima, Vânia Carneiro de Carvalho

The essay compares the curatorship's works realized during the decade of 1990 by the actual Department of Textual and Iconographical Documentation of Museu Paulista, responsible for the MP Fund / Permanent File (Fundo MP/Arquivo Permanente), hundreds of collections and textual funds and 50.000 iconography pieces, great part of which are gathered in photographic collections. It shows how the documentation work extrapolates the limits of SVDHICO in order to integrate itself with the group activities of the museum and with other research groups. It also points towards new work methodologies which allow to perform the curatorship in an integrated way with the interdisciplinary research and the culture diffusion.

KEYWORDS: Curatorship. Collections. Museu Paulista. Photography. Database. Fine Arts.

Anais do Museu Paulista. São Paulo. N. Sér. v. 10/11.p.259-304 (2002-2003) 